\title{
A NEW GENUS AND TWO NEW SPECIES OF THE CRUSTACEAN ORDER THERMOSBAENACEA FROM THE WEST INDIES
}

\author{
by \\ JAN H. STOCK \\ Institute of Taxonomic Zoology, University of Amsterdam, The Netherlands
}

\section{CONTENTS}

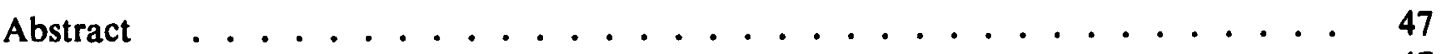

I. Introduction ......................... . . . 47

I.1. Discovery of West Indian taxa . . . . . . . . . . . . . . 48

1.2. Terminology ..................... . . 48

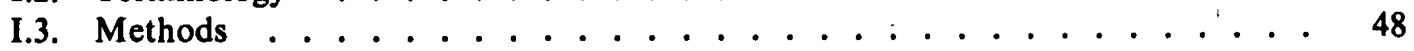

I.4. Acknowledgements . . . . . . . . . . . . . . . . 48

II. Monodella sanctaecrucis n. sp. . . . . . . . . . . . . . . . . . . . . 48

II.1. Material, localities, and description . . . . . . . . . . . . . 48

II.2. Affinities ...................... 56

III. Halosbaena acanthura n. gen., n. sp. . . . . . . . . . . . . . . . 56

III.1. Diagnosis of the new genus Halosbaena . . . . . . . . . . . . . . . . . 56

III.2. Material, localities, and description . . . . . . . . . . . . . 58

III.3. Affinities ..................... 64

IV. Limnosbaena n. gen. . . . . . . . . . . . . . . . . . . . . . 64

V. Key to the genera of Thermosbaenacea . . . . . . . . . . . . . . 65

VI. Distribution and origin of the Thermosbaenacea . . . . . . . . . . . . . . 65

Bibliography of the Thermosbaenacea and other references . . . . . . . 69

\begin{abstract}
Up to now, the crustacean order Thermosbaenacea contained two genera with only six valid species, five from the panmediterranean region, one from Texas.

Two new members of this curious group of "living fossils" have been discovered in the West Indies. The one, from two deep wells not far from the sea coast in Saint Croix (U.S. Virgin Islands), belongs to an undescribed species of the amphiatlantic genus Monodella, and is called $M$. sanctaecrucis.

The other was found in several localities in Curacao (Netherlands' Antilles), in coral débris of rubble walls on the shore; it belongs to a new genus, Halosbaena showing several remarkable adaptations, e.g. having a uniramous first pereiopod and reductions in the maxilliped. The presence of very numerous specialized elements on the second maxilla and some other characters relate Halosbaena remotely to a species from Jugoslavia, described as Monodella finki. Several other characters of the latter species justify the erection of a new genus for it, called Limnosbaena.
\end{abstract}

The literature on the possible origin of the Thermosbaenacea is reviewed. Based on the present and other recent discoveries, the origin of the genera Limnosbaena and Monodella (and possibly also of Thermosbaena) at the end of the Tethys period, from marine ancestors, is considered to be the most likely. For the genus Halosbaena a Pleistocene invasion of haline interstitial waters cannot be excluded.

\section{INTRODUCTION}

I.1. Discovery of West Indian taxa.

Thermosbaenacea are a rare order of Crustacea ("living fossils", according to Botosaneanu \& Delamare Deboutteville, 1967), with only six valid species (see \& VI). These show a relic-like distribution in brackish, or sometimes fresh, waters around the ancient Tethys basin, but were 
hitherto unknown from the West Indies. In the present paper, two taxa, both new, are recorded from two Caribbean islands, Saint Croix in the U.S. Virgin Islands, and Curaçao in the Netherlands' Antilles. Like several other members of the Thermosbaenacea, the two present taxa were found in close-to-the-sea habitats, and under hypogean conditions (deep wells and the macroporous interstitium of coral rubble).

The animals found in St. Croix belong to a new species of the genus Monodella Ruffo, 1949, M. sanctaecrucis $\mathrm{n}$. sp. Members of this genus were already recorded from both the Old World and the New World (Texas).

The specimens from Curaçao were found to represent an undescribed species of a new genus, Halosbaena acanthura $\mathrm{n}$. gen., n. sp.

\section{I.2. Terminology.}

The terminology of the appendages and components thereof follows closely Siewing's (1958) treatment. Because of lack of proof, no distinction has been made between coxopodal and praecoxopodal endites. Instead of the somewhat confusing terms "thoracopods 2 to 8 ", the usual "pereiopods 1 to 7" have been used. In the second antenna, the indications "protopodite" and "endopodite" have not been used, in analogy with the current terminology in other peracarids like amphipods.

\section{I.3. Methods.}

The samples from the deep wells in St. Croix were obtained with the aid of a "phreatobiological net" (Bou, 1975a: 616, fig. 2C) of a small size specially adapted to be lowered into drillholes with a 6" diameter.

The samples from interstitial waters in banks of coral rubble in Curaçao were collected with a "pump and corer" (Bou, 1975a: 612, fig. 2A).

The specimens were initially preserved in formalin $4 \%$, but for study transferred into lactophenol. Measurements of the entire body were taken in lactophenol. Dissected parts were mounted in Reyne's modification of Faure's medium. Drawings have been made from mounted appendages.

The chlorinities of the Curaçao localities have been determined according to the ASTM (American Society for Testing and Materials) method D 512, by the laboratory of Shell Curaçao N.V. In this context the assistance of $\mathrm{Mr}$. H. Bonvie is gratefully mentioned. For the Saint Croix chlorinities, formalin preserved water samples were tested with the aid of an E.E.L. electric chlorinimeter.

\section{I.4. Acknowledgements.}

The fieldwork in St. Croix was supported by a grant (WR 87-114) from the Netherlands' Foundation for the Advancement of Tropical Research (WOTRO), The Hague. The staff of the West Indies Laboratory, Fairleigh Dickinson University, St. Croix, offered much appreciated assistance during the fieldwork phase, more in particular Mr. Dick Holt who collected a number of additional samples after my departure.

The fieldwork in Curaçao was likewise supported by a grant from WOTRO (W 87-79). The hospitality of the Caribbean Marine Biological Institute is gratefully acknowledged.

Thanks are also due to Mr. C. Bou, of Albi (France) who provided the "pump and corer", developed by him, which proved to be a valuable tool for collecting groundwater animals.

Furthermore, I wish to acknowledge the help of Dr. P. de Buisonjé, of the Geological Institute, University of Amsterdam, in finding some references on Antillean geology and for discussions on the geological history of Curaçao.

\section{Monodella sanctaecrucis n. sp.}

\section{II.I. Material, localities, and description.}

Material and localities. -

All from Saint Croix (U.S. Virgin Islands):

- A deep well (6" drill-hole) in a meadow at the Union \& Mount Washington Estate, about $1 \mathrm{~km} \mathrm{~N}$. of the shore of Great Pond (a salt pond). The well is situated on the W.-side of the road, behind a low dam, and is provided with a ramshackled windmill. Altitude of the ground surface almost $20 \mathrm{~m}$, water-level at almost $-15 \mathrm{~m}$. Chlorinity $990 \mathrm{mg} /$. Approximate geographic position of the well: $17^{\circ} 44^{\prime 2} 23^{\prime \prime} \mathrm{N}$ $64^{\circ} 39^{\prime} 33^{\prime \prime}$ W. Nov. 20, 1975. Holotype: 1 \% with empty brood pouch, allotype: $1 \delta$, and 4 paratypes: $1 \%$ without brood pouch, 1 juvenile $\$, 1 \delta, 1$ juvenile $\delta$. Preserved in the Zoölogisch Museum, Amsterdam (cat. no. ZMA CrA. 80018003). One additional male was collected by Mr. Holt at the type locality in early January 1976.

- A deep well in Mr. Roebuck's meadow, Estate Solitude; approximate geographic position $17^{\circ} 45 / 22^{\prime \prime} \mathrm{N} 64^{\circ} 3804^{\prime \prime} \mathrm{W}$. The well is provided with an electric, submersible pump placed at $-48 \mathrm{~m}$ depth, thus well below sea-level since the opening of the well lies at an altitude of some $24 \mathrm{~m}$. Distance from the sea: $500-600 \mathrm{~m}$. Chlorinity $540-580 \mathrm{mg} /$. Early January 1976, collected by Mr. D. Holt. Two fragmentary 


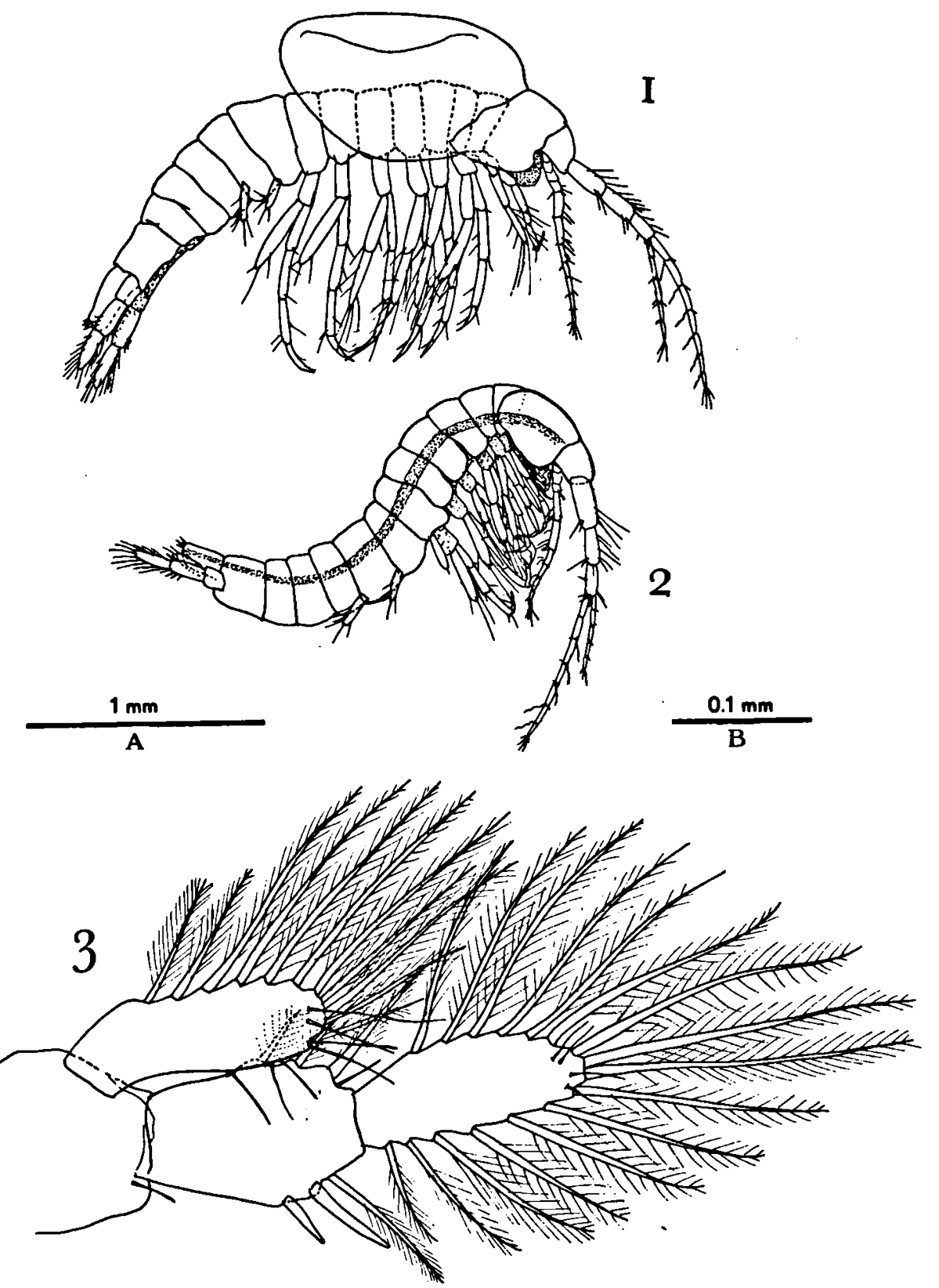

Figs. 1-3. Monodella sanctaecrucis n. sp., paratypes. 1, female with empty brood pouch, from the right (scale A); 2, male, from the right (scale A); 3, uropod, $\delta$ (scale B).

specimens, preserved in the Zoölogisch Museum, Amsterdam.

Accompanying fauna. - At the type-locality, the accompanying fauna consisted of Oligochaeta, Cyathura sp. (Isopoda), and Collembola. At the other locality, Cyathura was numerous, as was an amphipod of the genus Metaniphargus.

\section{Description. -}

Length of the body of the two adult females (frontal margin head to tip of telson) 2295 and
$2247 \mu \mathrm{m}$; of the two adult males this length is 1654 and $2352 \mu \mathrm{m}$. The length of the brood pouch is $1033 \mu \mathrm{m}$.

The anterior part of the head is not covered by the carapace (figs. 1, 2). Posteriorly, the carapace partially covers pedigerous somites 1 and $2(\%)$ or $1\left(\sigma^{*}\right)$ (pedigerous somite 1 is homologous with thorax somite 2). The brood pouch in $\%$ (fig. 1) covers dorsally and laterally pedigerous somites 1 
to 6. There are 7 pairs of biramous pereiopods and 2 pairs of uniramous pleopods, the latter on abdominal somites 1 and 2 . Abdominal somites 3 , 4 and 5 are unarmed. Abdominal somite 6 bears the "free" (i.e., basally articulated) telson and a pair of uropods.

Females differ in external morphology from the males (1) in the structure of the maxilliped (devoid of endopod in $\%$ ), (2) in the absence of a penis (present in $\delta$ on pereiopod 7), (3) in the lower number of aesthetes on $\mathrm{Al}$; and (4) in the presence, during certain phases of life, of a dorsal brood pouch (when this pouch is absent, only differences (1), (2) an (3) are valid).

The following description of the appendages is based on the male morphology, but careful comparison with dissected and mounted female appendages has not revealed any differences, except for in the first antenna, the maxilliped and 7th pereiopod.

The first antenna (fig. 4) has a 3-segmented peduncle (protopodite) and 2 flagelli. The main flagellum (exopodite) is 7-segmented, the accessory flagellum (endopodite) is slightly over half the length of the main one and is 5-segmented. All antennular articles are relatively slender. The peduncle articles dorsally bear 3, 4, and 2 long plumose setae, respectively. Peduncle article 3 , bears a low, setiferous swelling between the implantation of exo- and endopodite. All articles of the main flagellum, except for the most distal one, bear a long aesthete, which consists of a stiff basal part ("grip") and a supple distal part ("whip") (fig. 5). In the female, the proximal flagellar articles are devoid of aesthetes.

The second antenna (fig. 11) is uniramous. From the point of view of comparitive anatomy, one might expect (Siewing, 1958) the presence of a 3-segmented protopodite and a multiarticulated endopodite. In analogy with the terminology used in Amphipoda, however, I prefer to designate the antennal articles as 5 peduncle segments (3 shorter, 2 longer), and 5 flagellum segments. Peduncle articles 4 and 5 are of equal length. The armature of the 2 nd antennae consists of short, naked setae in the arrangement shown in the figure.

The labrum (fig. 12) is shaped like the human tongue; at its posterior margin it bears numerous small spinules.

The mandible (fig. 7) consists of a corpus mandibulae and a 3-segmented palp. The basal palp article is short and unarmed; articles 2 and 3 are slender, 3 is subequal to 2 ; article 2 bears 1 very strong ventral spine having ciliated margins; similar spines, though less strong and 6 in number, occur on the ventral margin of article 3; distally, article 3 bears 1 short and 2 longer, naked setae. The corpus mandibulae is differentiated into a pars incisiva (p.i.), a lacinia mobilis (1.m.), and a pars molaris (p.m.); between the lacinia mobilis and the pars molaris, a row of 6 or 7 ciliated spines is implanted. The pars incisiva is slightly asymmetrical (figs. 7 and 8 ), and so is the lacinia mobilis, which bears 2 marginal denticles in the right mandible, 3 subterminal denticles in the left one.

Closely associated with the mandible is a hairy lobe, interpreted as paragnath (pgn. in fig. 7). Several other hairy lobes occur in the oral area and are probably carapace flaps (Barker, 1962: 267).

The first maxilla (fig. 9) bears: (1) a coxopodal endite (c.e.) with a medial armature of 2 plumose setae and a naked seta, and a terminal armature of 8 plumose setae; (2) a basipodal endite (b.e.) with a distal armature of 5 saw-like teeth (cf. fig. 9, detail); (3) a "palp" (= endopodite) consisting of 3 articles: a small, unarmed basal article; a long 2 nd article, armed with 4 naked setae and 2 very strong, unilaterally toothed, spines (fig. 9 , detail); and a small terminal article armed with 2 distal setae.

The second maxilla (fig. 10) is complexly built: one can distinguish a protopodite, 1 coxopodal endite, 2 basipodal endites, a well-developed endopodite, and a rudimentary exopodite. The protopodite bears numerous setae, only 2 of which are plumose. The coxopodal endite (c.e.) bears 6 plumose setae. The first basipodal endite (b.e. 1) bears a distal row of 10 to 15 hooked spines, which are distally barbed (see fig. 10, detail); 2 similar spines, but longer, are implanted subterminally. The 2 nd basipodal endite (b.e. 2) is vaguely 2-segmented; distally, it bears 4 hooked, terminally barbed, spines; 2 similar, but longer, spines are implanted subterminally. The exopodite (ex.) is reduced to a triangular lobe armed with 1 distal seta. The endopodite (end.) is 2-segmented; segment 1 is unarmed, segment 2 bears 7 naked setae.

The labium (fig. 6) is a deeply cleft, ciliated lobe.

The maxilliped is sexually dimorphic. In the 


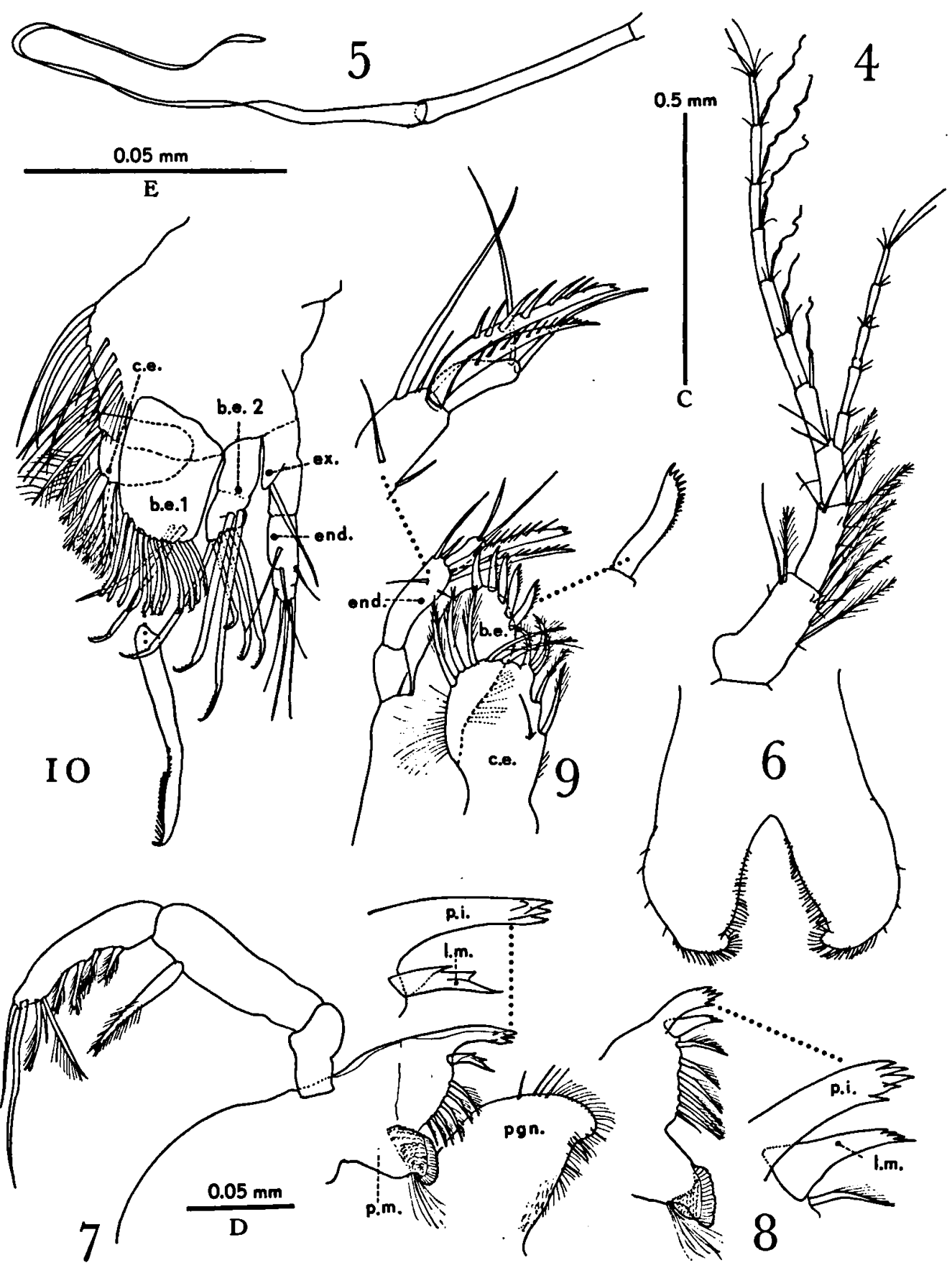

Figs. 4-10. Monodella sanctaecrucis n. sp., $\delta$, paratype. 4, first antenna (scale C); 5, aesthete of proximal article of main flagellum of first antenna (free-hand sketch); 6, labium (scale D); 7, right mandible and paragnath (pgn.) (both to scale D) (p.m. = pars molaris) and its pars incivisa (p.i.) and lacinia mobilis (l.m.) more strongly enlarged (scale E); 8, masticatory part of left mandible (scale D) and its pars incisiva (p.i.) and lacinia mobilis (l.m.) more strongly enlarged (scale E); 9, first maxilla (scale D), one of the spines of the basipodal endite and the palp more strongly enlarged (both to scale E) (c.e. = coxopodal endite; b.e. $=$ basipodal endite; end. = endopodite transformed into a palp); 10, second maxilla (scale D) (c.e. = coxopodal endite; b.e. 1 and b.e. $2=$ first and second basipodal endites; end. = endopodite transformed into a palp; ex. = rudimentary exopodite). 


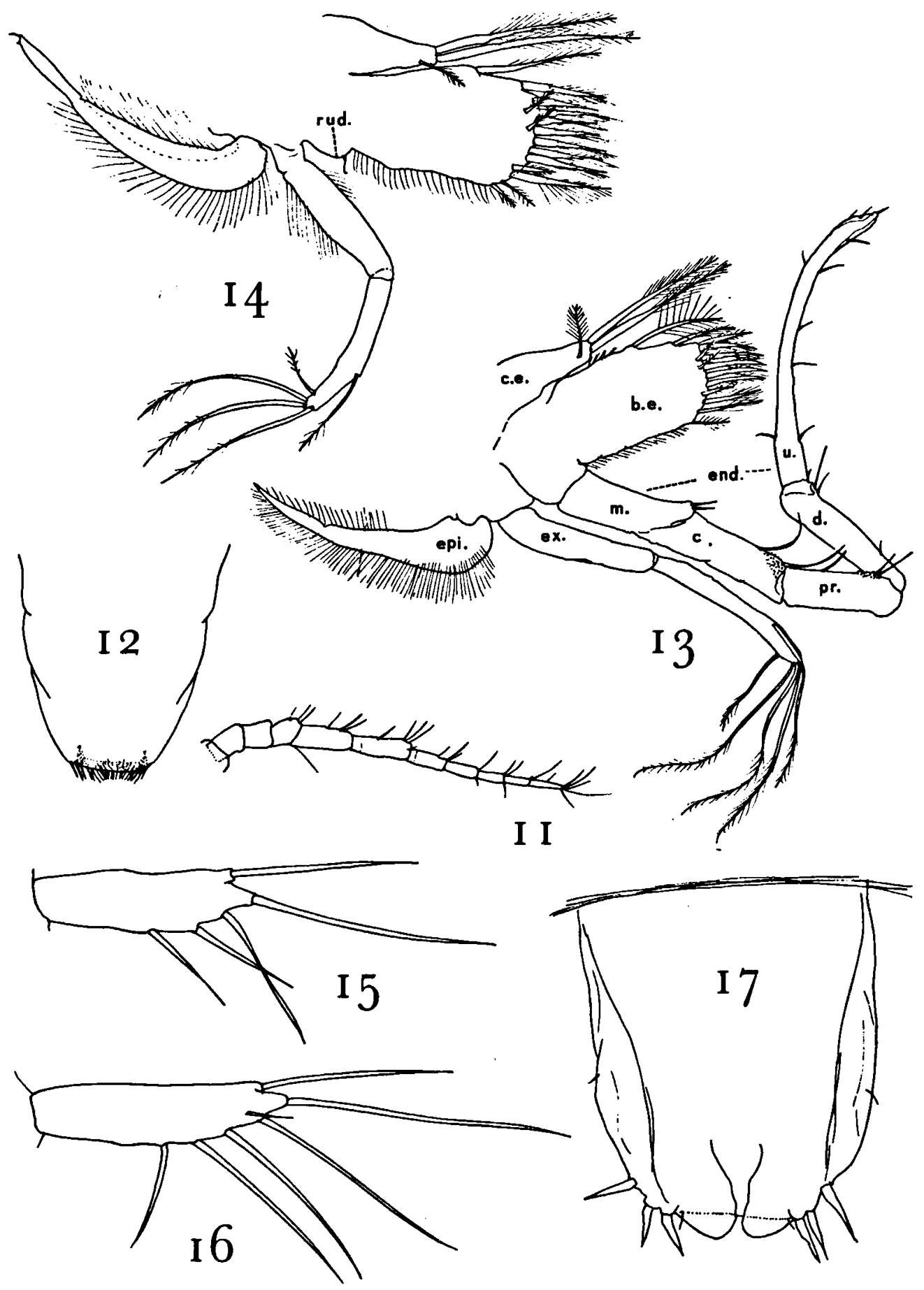

Figs. 11-17. Monodella sanctaecrucis n. sp., paratypes. 11, second antenna, $ठ$ (scale C); 12, labrum, (scale D); 13, maxilliped, $\delta$ (scale B) (c.e. = coxopodal endite; b.e. = basipodal endite; epi. = epipodite; ex. = exopodite; end. = endopodite; the five articles of the endopodite are $\mathbf{m} .=$ merus, $\mathrm{c}$. $=$ carpus, pr. $=$ propodus, $\mathrm{d}$. = dactylus, and $u$. = ungulus); 14, maxilliped, $\$$ (scale B) (rud. = rudiment of endopodite); 15, first pleopod, $\delta$ (scale D); 16, second pleopod, $\delta$ (scale D); 17, telson, $\delta$ (scale B). 
male (fig. 13), one can distinguish a coxopodal endite (c.e.), a basipodal endite (b.e.), an endopodite (end.), an exopodite (ex.), and an epipodite (epi.). The coxopodal endite is a tapering lobe armed with 1 short and 2 long setae, all plumose. The basipodal endite bears 2 medial, plumose setae, 8 longer, terminal plumose setae, and 4 shorter, subterminal, plumose setae. The endopodite is 5-segmented: segment 1 (merus, $\mathrm{m}$. in fig. 13) bears two short mediodistal setules; segment 2 (carpus, c.) bears 1 medial and 1 medioterminal setae, and a patch of rugosities; segment 3 (propodus, pr.) bears 1 medial and 2 medioterminal setae and a patch of rugosities; segment 4 (dactylus, d.) is slightly longer than the propodus and armed with a few short lateral setules; segment 5 (ungulus, u.) is curved, almost twice as long as segment 4 and armed with a number of short setules. The exopodite (ex.) consists of 2 slender articles, the distal one with 3 terminal and 2 subterminal, plumose setae. The epipodite (epi.) is a tapering lobe with ciliated margins.

The female maxilliped (fig. 14) resembles that of the male, with the exception of the reduction of the endopodite to a small, rounded lobe provided with a setule (rud. in fig. 14).

The 1st pereiopod (fig. 18) bears 3 short setae on the basipodite. The exopodite is 2 -segmented: the basal article is unarmed, the distal article bears 2 lateral, 3 medial and 4 (sub)terminal setae, all plumose. The endopodite has a clearly demarcated, "free", ischium (i. in fig. 18); the merus (m.) is the longest article; the carpus (c.) is short, armed with 3 longish setae; the propodus. (pr.) is longer again, armed with 3 setae in its distal half, and moreover with a long medioterminal, bicuspidate, spine (fig. 19). Dactylus (d.) and ungulus (u.) are separated by an articulation; the dactylus bears a thinner and a heavier seta on its inner margin; the ungulus is finely crenulated at the tip (fig. 19).

The 2nd pereiopod (fig. 20) is larger than the first. The exopodite bears 2 spinules on the medial margin of article 1 ; article 2 is fundamentally armed as in pereiopod 1. The endopodite shows an almost complete fusion of ischium and merus. The propodus and dactylus show a row of spinules running over their surface. The inner margin of the dactylus bears a short and a very long seta (fig. 21). The ungulus is very long and slender.
The 3rd pereiopod (fig. 22 ) resembles the 2 nd. The ischium and merus of the endopodite are completely fused; the propodus but chiefly the carpus are more elongate than in P2.

The 4th pereiopod (fig. 23) is very similar to the 3rd, except for the slightly shorter and more slender endopodal ungulus, and the absence of a row of spinules on the surface of the endopodal dactylus.

The 5th pereiopod (fig. 24) though fundamentally built as the 4th, differs in having a shorter, and differently armed exopodite. Exopodite article 1 lacks medial spinules, but bears a medioterminal plumose seta. Exopodite article 2 is armed with 2 or 3 medial setae, 3 (sub)terminal setae, and 1 lateral seta, all plumose.

The 6th pereiopod (fig. 25) has an elongate, uniarticulated exopodite, which bears a few medial and lateral setules, a medio-subterminal seta (plumose) and 2 distal setae (1 long and plumose, 1 short and naked). The endopodite is similar to that of P5.

The 7th pereiopod (fig. 26) has a slightly shorter exopodite than P6. Most distinctive is the presence of an elongated, sausage-shaped, penis (pen.) associated with the coxopodite.

The first pleopod (fig. 15) has 3 marginal, 1 terminal, and 1 subterminal setae.

The second pleopod (fig. 16) has 4 marginal, 1 terminal, and 1 longer and 1 shorter subterminal setae.

The uropod (fig. 3) has a 2-segmented exopodite and a 1-segmented endopodite. Exopodite articles 1 and 2, and the endopodite article are more or less equal in length. Exopodite article 1 has a lateral armature of 2 spines and 1 plumose seta, and a medial armature of 3 plumose setae and a setule. Exopodite article 2 bears plumose setae all along the medial, terminal and lateral margins. The endopodite bears long, plumose setae on the medial and terminal margins, and short, naked setae subterminally and laterally.

The telson (fig. 17) is a more or less rectangular lobe, longer than wide, carrying on the two distal corners a group of 3 spines, medially separated by a rather wide, unarmed stretch.

Juvenile specimens differ from adults in a smaller size, a lower number of articles in the flagellum of $\mathrm{Al}$, and a shorter penis. No fundamental differences have been found in the structure of 2 nd antenna, pereiopods, pleopods, and uropods. 


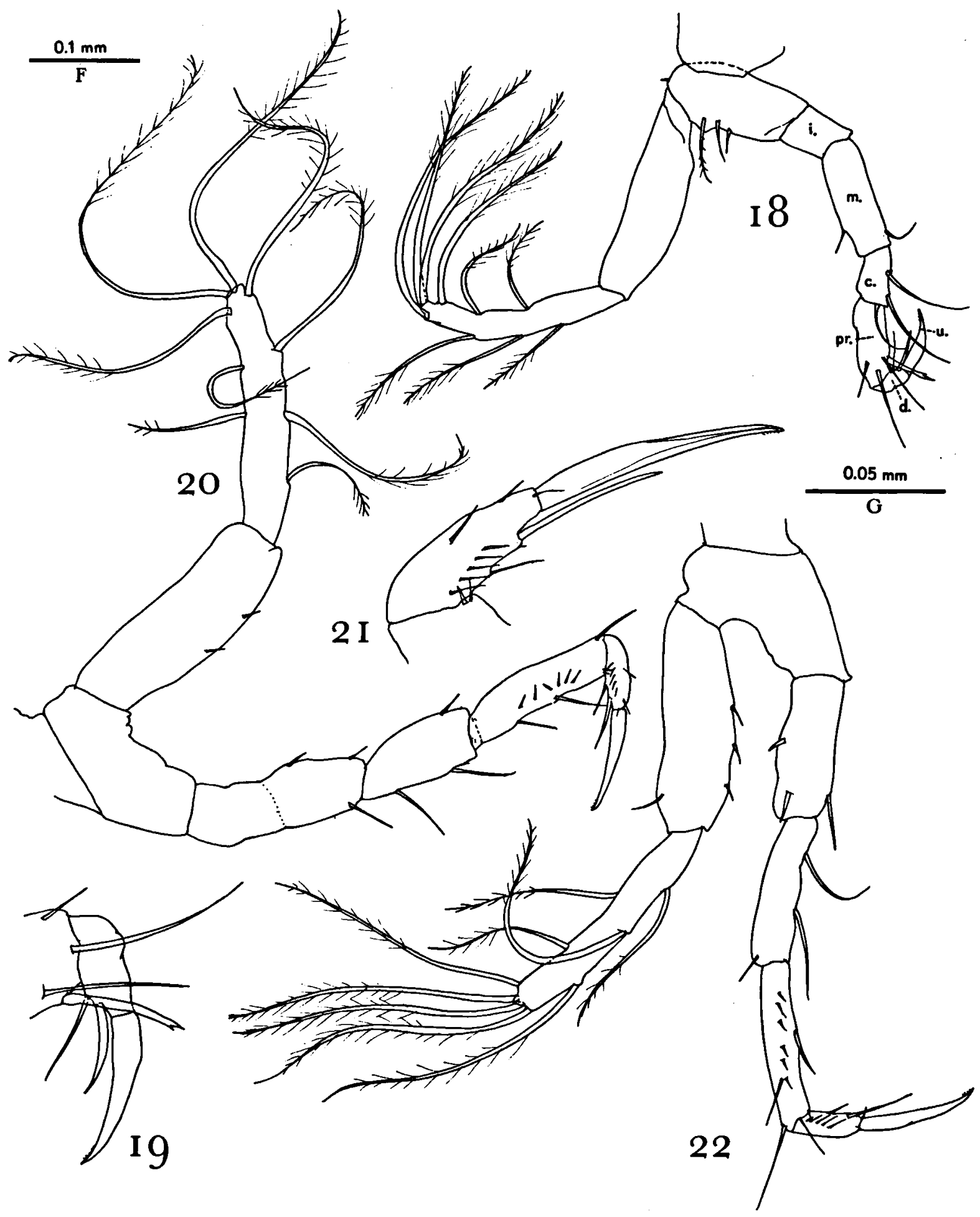

Figs. 18-22. Monodella sanctaecrucis n. sp., ơ, paratype. 18, first pereiopod (scale F) (i. = ischium; $m$. = merus; c. = carpus; pr. = propodus; $d$. = dactylus; $u$. = ungulus); 19, distal endopodite articles of first pereiopod (scale G); 20 , second pereiopod (scale F); 21, distal endopodite articles of second pereiopod (scale G); 22, third pereiopod (scale F). 


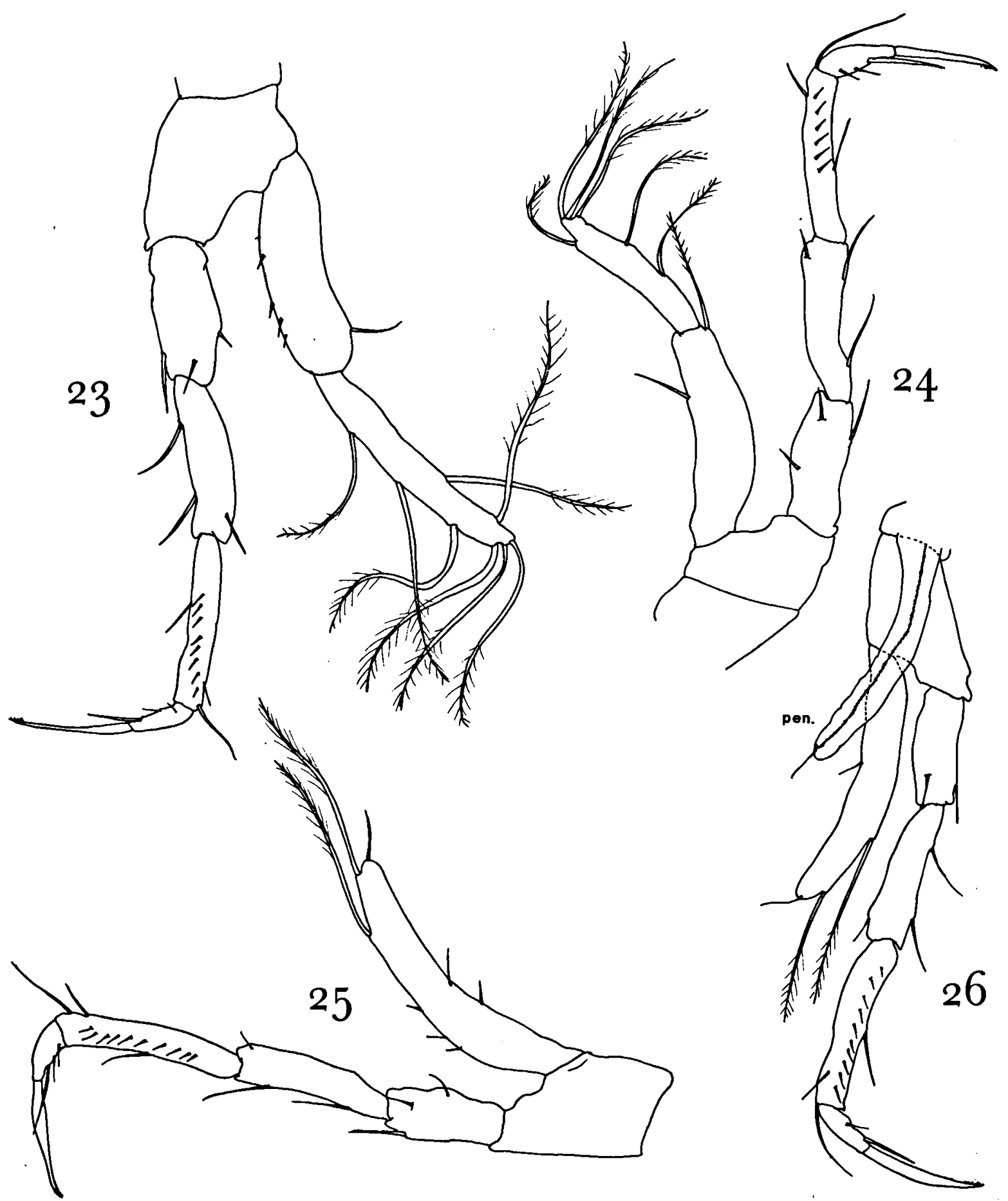

Figs. 23-26. Monodella sanctaecrucis n. sp., $\delta$, paratype. 23, fourth pereiopod; 24, fifth pereiopod; 25 , sixth pereiopod; 26 , seventh pereiopod (pen. = penis) (all to scale $F$ ). 


\section{II.2. Affinities.}

The presence of a dorsal brood pouch in the female, the characteristic shape of the male maxilliped, the extension of the carapace, and the presence of a lacinia mobilis in the mandibles, demonstrate with absolute certainty that the St. Croix crustaceans belong to the Thermosbaenacea. Within that order, they show all salient characters of the genus Monodella (e.g., seven instead of five - pairs of pereiopods, a free telson, a sexually dimorphic maxilliped, etc.).

The Caribbean material, though showing an overall resemblance to all other Monodella's (except $M$. finki, which differs so markedly from all other species that a separate generic status for this species will be proposed in 8 IV), is sufficiently distinct to warrant the creation of a new species, called after the type-locality Monodella sanctaecrucis $n$. sp. The differences from the previously described taxa are discussed below:

- The type-species, $M$. stygicola Ruffo, 1949, is based on juvenile, presumably female, specimens (body length $1.5 \mathrm{~mm}$ only), having a shortish 3rd article in the mandibular palp (very elongate in sanctaecrucis), an anaxially articulated 3rd endopodite article in maxilla 1 (synaxially in sanctaecrucis), a telson that is wider than long (longer than wide in sanctaecrucis), and an elongately rectangular first exopodite article in the uropod (wider and more ovate in sanctaecrucis). When adult material of $M$. stygicola turns up, further differences might be found. The chief point of agreement between stygicola and sanctaecrucis is the presence of a 3-segmented "palp" (= endopodite) in maxilla 1 (in the remaining species of Monodella only a 2-segmented endopodite has been signalized).

- M. relicta Pór, 1962, has very short and thickset peduncular and flagellar articles in the first antenna (slender in sanctaecrucis). The endopodite of maxilla 1 is 2-segmented (3-seg mented in sanctaecrucis). The distal endopodite article of the male maxilliped is short and clublike (very slender and claw-like in sanctaecrucis); the entire endopodite is composed of 6 articles (5 in sanctaecrucis); in the first pereiopod, the propodus is the longest endopodite article (in sanctaecrucis the merus is the longest).

- As to $M$. argentarii Stella, 1951, I based myself chiefly on Rouch's (1965) perfect account, and $I$ accepted his proposal to consider $M$. halophila identical with argentarii. This species differs from sanctaecrucis in having a 2-segmented endopodite in maxilla 1 (versus 3-segmented), in having a more elongate, rectangular basal exopodite article of the uropod (wider and more ovate in sanctaecrucis), in having a row of plumose setae along the entire lateral margin of the uropodal endopodite (a few naked setae in the distal part of the medial margin in sanctaecrucis). The carpus of the endopodite in pereiopod 2 is linear and very slender (much less slender in sanctaecrucis). Moreover, the lengths of dactylus and claw in the endopodite of the male maxilliped are mutually much more different in sanctaecrucis than in argentarii.

- M. texana Maguire, 1965 , is the only species found in the New World. It differs from $M$. sanctaecrucis in having a 2-segmented endopodite in maxilla 1 (versus 3-segmented), and a 4segmented exopodite in the $\delta$ maxilliped (versus 2-segmented). The peduncular articles of antenna 1 are less slender than in sanctaecrucis. In the 2nd antenna, article 4 is much longer than article 5 in texana, whereas articles 4 and 5 are subequal in sanctaecrucis. There might be other differences as well, but some of the figures of $M$. texana in Maguire's paper are on so small a scale that details are not clearly discernible.

- From Monodella (now Limnosbaena, see \& IV) finki Meštrov \& Lattinger-Penko, 1969, the Saint Croix specimens differ in characters of generic level enumerated in table I. On the specific level, the length of the distal endopodite article (ungulus) in the $\delta$ maxilliped is distinctive (short, but with 2 long terminal elements in finki; very elongate, armed with several quite small terminal and lateral elements in sanctaecrucis). A remarkable point of agreement between finki and sanctaecrucis is the presence of an articulated, well-individualized ischium in the endopodite of pereiopod 1 (usually fused with the basipodite in other thermosbaenaceans).

\section{Halosbaena acanthura n. gen., n. sp.}

\section{III.1. Diagnosis of the new genus Halosbaena.}

Thermosbaenacea with 7 pairs of pereiopods and a free telson. Rostrum present, bilobed. First antenna with normal number of flagellum articles (about 9 in main flagellum, 5 or 6 in accessory flagellum). Limit between peduncle and flagellum in second antenna not clearly marked. 


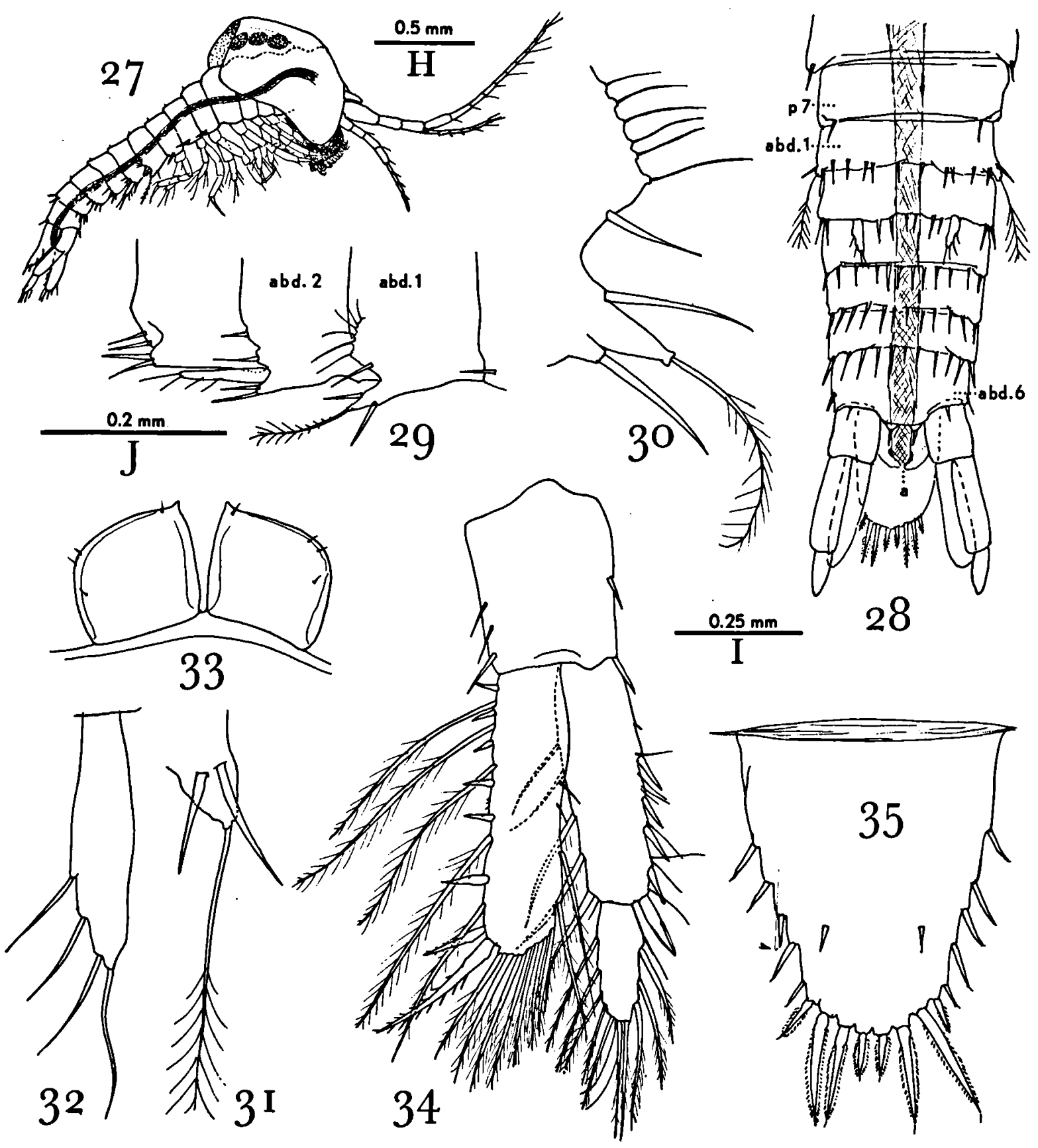

Figs. 27-35. Halosbaena acanthura n. gen., n. sp., paratypes. 27, ovigerous female, from the right (scale H); 28 , last thoracomeres (pereiopods omitted) and abdomen, $\delta$, ventral (armature of the uropods omitted) (scale I); 29, abdominal somites 1 to 3, from the right, showing pleopods 1 and 2, $q$ (scale J); 30 , left pleopod 1 , and associated structures, lateral view, $\$$ (free-hand sketch); 31 , left pleopod $1, \%$, ventral (scale G); 32, right pleopod 2, \&, ventral (scale G); 33, rostrum, $\delta$ (scale F); 34, uropod, $\%$ (scale F); 35, telson, ¿ , dorsal (scale F).

$a=$ anus; abd. $1-6=$ abdominal somites 1 to $6 ; p 7=$ somite bearing pereiopods 7 . 
Lacinia mobilis distinct in left mandible, probably absent in right mandible; processus molaris ciliated, wedge-shaped. Second maxilla with plate-like, unarmed exopodite, and widened basipodal endites 1 and 2, each provided with very numerous rake-like elements. Maxilliped not sexually dimorphic, exopodite reduced to a poorly armed lobe, endopodite reduced to a ciliated stretch. First pereiopod uniramous, probably through reduction of the exopodite; presumed endopodite with free basis, ischium and merus. Second through seventh pereiopods with 2 -segmented exopodites. First pleopod fused with pleosomite 1, second pleopod well-articulated. Telson tongue-shaped, with spiniferous lateral margins. Uropods with 2-segmented exopodite, second segment half as long as the first.

Monospecific, type-species Halosbaena acanthura n.sp.

\section{Derivatio nominis. -}

The generic name alludes to the Greek words ä $\lambda s$ (salt) and Baiveiv (to walk), and refers to the high salt concentrations in the habitat. The specific name is based on the words äkavea (spine) and oupá (tail) and refers to the rows of strong spines on the abdomen.

\section{III.2. Material, localities, and description.}

Material and localities. -

All from Curaçao (Netherlands' Antilles):

- Holotype: $1 \%$, allotype: $1 \delta$, paratypes: $7 \% q$ and $3 \delta \delta$. Preserved in the Zoologisch Museum, Amsterdam (cat. no. ZMA CrA. 8006 -8009). South shore of lagoon Zakitó, along John F. Kennedy Boulevard (approximate geographic position $12^{\circ} 0702^{\prime \prime} \mathrm{N} 68^{\circ} 57^{\prime} 33^{\prime \prime} \mathrm{W}$ ). Muddy, much plant remains, partly rotting; chlorinity $35640 \mathrm{mg} /$. Nov. 20, 1973. Accompanying fauna: numerous amphipods of the Hadzia-group.

- $1 \delta, 1$ damaged specimen. Land side of coral rubble wall, shore of small pool on the beach, south side of John $F$. Kennedy Boulevard (near previous station, but some $50 \mathrm{~m}$ more seaward). Muddy sand and coral débris; chlorinity $31482 \mathrm{mg} /$. Nov. 20, 1973. Accompanying fauna: a few amphipods of the Hadzia-group.

- 1 \%. Piscadera Innerbaai, east side of mouth, about $100 \mathrm{~m}$ inland of the shack of "American Rent a Boat" (approximate position $12^{\circ} 07^{\prime} 35^{\prime \prime} \mathrm{N} 68^{\circ} 5801^{\prime \prime} \mathrm{W}$ ). Coral sand, rubble, partly artificial. Chlorinity $35046 \mathrm{mg} /$; temperature $26.5^{\circ} \mathrm{C}$. Nov. 30 , 1973. Accompanying fauna: Uca sp., cyclopoid copepods.

- 1 \&. Santa Martha Bay, inside of coral rubble wall facing a small lagoon, just in front of (former) Coral Cliff Hotel (approximate position $12^{\circ} 16^{\prime} 13^{\prime \prime} \mathrm{N} 69^{\circ} 07^{\prime} 30^{\prime \prime} \mathrm{W}$ ). Coral rubble, clean. Chlorinity $32670 \mathrm{mg} /$. Dec. 16, 1973. Accompanying fauna: none.

-1 j. West side of Jan Thiel Bay, shore of brackish (probably temporary) pool (approximate position $12^{\circ} 04^{\prime} 49^{m} \mathrm{~N}$ $6^{\circ} 52^{\prime} 37^{\prime \prime} \mathrm{W}$ ). Very clean coral débris. Chlorinity $23760 \mathrm{mg} /$, temperature $26.8^{\circ} \mathrm{C}$. Dec. 22, 1973 . Accompanying fauna: none.

$-1 \delta, 1$ dagamed specimen. Blauw Bay, in supralittoral (spray zone), just in front of the entrance of Blauw Bay. cave

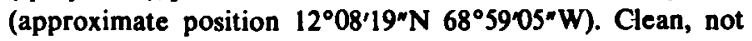
much sand. Chlorinity $17820 \mathrm{mg} /$, temperature $27.4^{\circ} \mathrm{C}$. Jan. 4, 1974. Accompanying fauna: a few amphipods of the Hadzia-group.

\section{Description. -}

Length of the body (frontal margin carapace, without rostrum, to tip of telson) of four females $1705,1761,1774$, and $1916 \mu \mathrm{m}$, of four males $1668,1719,1720$, and $1720 \mu \mathrm{m}$.

The entire head is covered by the carapace; posteriorly, the carapace reaches the 6 th pedigerous somite (in fig. 27, of a female with eggs in the brood pouch, the posteriad extension of the carapace is less clearly observed than in "empty" females or males). Anteriorly, just over the bases of the first antennae, there are two rostal lobes, roughly squarish in outline, rounded laterally and pointed medially (fig. 33). There are 7 pairs of pereiopods and 2 pairs of pleopods. Abdominal somites 3, 4, and 5 do not bear appendages; abdominal somite 6 bears an articulated telson and a pair of uropods. Dorsally, a minute setule is implanted on pedigerous somites 5,6 , and 7 , and on abdominal somites 1 to 4; abdominal somite 5 bears 1 mid-dorsal spine and 1 spine on either side; abdominal somite 6 bears 1 mid-dorsal spine. Laterally, a strong spine is implanted on pedigerous somites 5 to 7, just above the insertion of the legs. The lower lateral surface and the ventral surface of the abdominal somites 1 to 5 bear some 10 to 12 long spines (fig. 28). Abdominal somite 6 bears 2 spines on either side; near the mid-ventral line, this somite bears 2 spiniferous knobs (fig. 28).

Females differ in external morphology from males in the absence of a penis on pedigerous somite 7 , and in the presence, during certain phases of life, of a space between the carapace and the dorsal surface of the body in which the eggs develop.

Since the sexes are so similar, the following description of the appendages applies to both male and female.

The first antenna (fig. 36) has a 3-segmented peduncle (protopodite), and 2 flagelli. Peduncle segment 3 bears distally 2 spines and a triangular process armed with 3 naked setae (fig. 38). The 


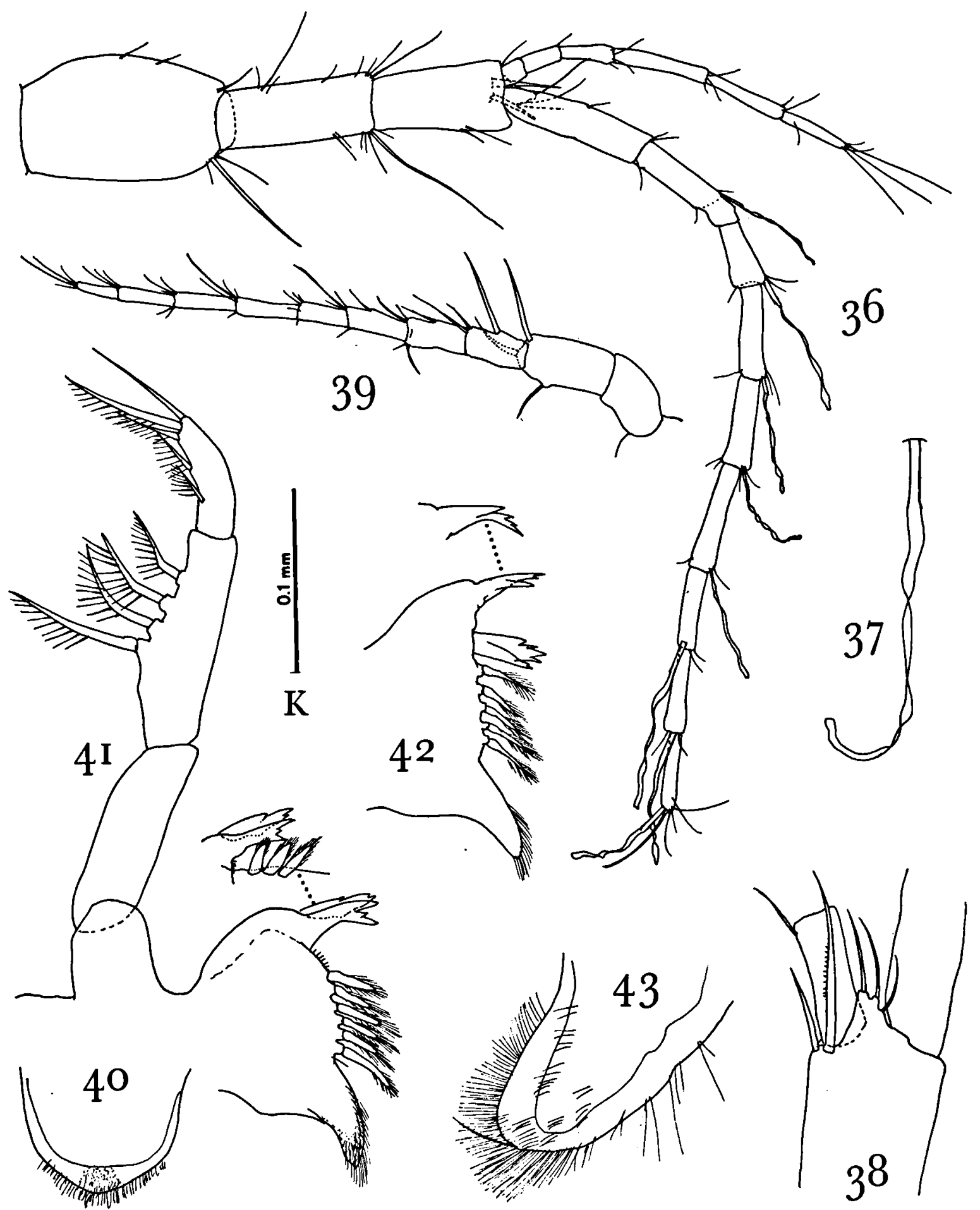

Figs. 36-43. Halosbaena acanthura n. gen., n. sp., paratypes. 36, first antenna, $\$$ (scale F); 37, aesthete of first antenna, $\$$, more strongly enlarged; 38, distal part of peduncle and basal part of flagelli of first antenna, $\%$ (scale G); 39 , second antenna, $\%$ (scale F); 40, labrum, $\delta$ (scale K); 41, right mandible, $\%$ (pars incisiva also drawn from a different angle) (scale G); 42, same for left mandible. $\&$ (scale G); 43 , paragnath, $\$$ (scale G). 
main flagellum (exopodite) consists usually of 9 articles, all except the most proximal one bearing an aesthete (fig. 37). The accessory flagellum (endopodite) is 5- or 6-segmented.

The second antenna (fig. 39) is weak. It has an unarmed basal article; article 2 is the longest and thickest; articles 3,4 and 5 bear a strong resemblance to flagellum articles, except for having a mediodorsal seta which lacks in the 5 flagellum articles.

The labrum (fig. 40) is about as long as wide; its posterior margin is ciliated.

The mandible (fig. 41) has a well-developed, 3segmented palp. The basal palp segment is unarmed; segment 2 is the longest, segment 3 the shortest; segment 2 bears ventrally 4 graduated, pectinated spines (the most proximal of which is the longest); segment 3 bears also 4 such spines, but here the distalmost is the longest; moreover, segment 3 possesses a naked terminal seta. The corpus mandibulae of the left mandible (fig. 42) is differentiated into a quadridentate pars incisiva, a lacinia mobilis with 6 distal and marginal teeth, a row of 5 ciliated spines, and a pars molaris which is pointedly triangular, untoothed but provided with numerous cilia. In the right corpus mandibulae (fig. 41), the pars incisiva is made up of two processes, each with 3 teeth. Unless one of these two processes is the lacinia mobilis (which is unprobable since the process nearest to the spine row is not proximally articulated), the lacinia mobilis is represented but by a short stretch of minute spinules. There are furthermore 6 ciliated spines; the pars molaris is similar to that of the left mandible.

Closely associated with the mandible is a hairy lobe (fig. 43) interpreted as paragnath.

The first maxilla (fig. 44) is differentiated into the following parts: (1) a coxopodal endite (c.e.) with a medial armature of 13 plumose setae; (2) a basipodal endite (b.e.) with 6 denticulated spines, and 1 strongly transformed, tricuspidate, spine; (3) an endopodite (end.) consisting of 2 articles, armed with 2 setae and with 5 setae +2 spines, respectively.

The second maxilla (fig. 45) is a most complex structure. The homologies of the composing parts are presumably as follows: (1) the endopodite ("palp") consisting of 2 articles, 1 naked, the other with 5 long, naked setae; (2) a plate-like, unarmed lobe, which might be the exopodite, although its position (between endopodite and basipodal endite 2) makes this homology uncertain; (3) the lateralmost basipodal endite armed with numerous transformed, rake-like, spines; the distal, combed, ends of these spines form 10 transverse rows; altogether, there are some 110115 spines on this endite; (4) the medialmost endite, armed with 2 transverse rows of rake-like spines, 1 longer such spine, and 1 plumose seta; of the shortest rake-like spines there are 26 , of the longest there are 15 ; (5) the remaining part of the appendage may be a coxopodal endite; it bears 3 groups of setae: a proximal group of 7 plumose setae, a central row of about 24 , mostly naked, setae, and a distal group consisting of 5 transformed setae (see fig. 45, detail) and 8 normally plumose setae.

The maxilliped (fig. 46) is reduced in comparison with other thermosbaenaceans. The epipodite (epi.) is finger-shaped, obtuse at the tip, ciliated. The exopodite (ex.) is basally not articulated; it is an elongate ovate lobe, distally with 2 small spines. A plate-like lobe, fused with the exopodite and with the basipodal endite, is interpreted as the endopodite (end.); it has a ciliated free margin. The basipodal endite (b.e.) bears a complex distal armature, consisting of some 10 plumose setae, 7 denticulated spines (fig. 46, detail), 5 curved, curiously transformed spines (fig. 46, detail), and 1 long, denticulated spine with 4 spinules on its proximal part; moreover, the basipodal endite is provided with a medial plumose seta. A triangular lobe with $4+$ 1 plumose setae probably represents the coxopodal endite.

The first pereiopod (fig. 47) has only one ramus, judging from the fact that all articles are well-articulated and not mutually fused, the endopodite. The coxopodite bears a group of cilia but is otherwise unarmed. The basis is the longest article; it is unarmed except for a ciliated stretch near its proximal end. The ischium bears 1 subterminal spinule. The merus bears 1 longer (medial) and 1 shorter (lateral) subterminal seta. The carpus bears 3 strong, naked setae. The propodus is distally widened; it bears 4 strong, naked medial setae and 1 slightly sigmoid, naked lateral seta. A narrow and small distal segment probably represents the (transformed) dactylus; it carries 2 unequal, naked setae and 2 hooked and pectinated claws.

The 2 nd through 7 th pereiopods (figs. 50, 51, $48,49,52$ and 53 , respectively) have 2 -segmented 


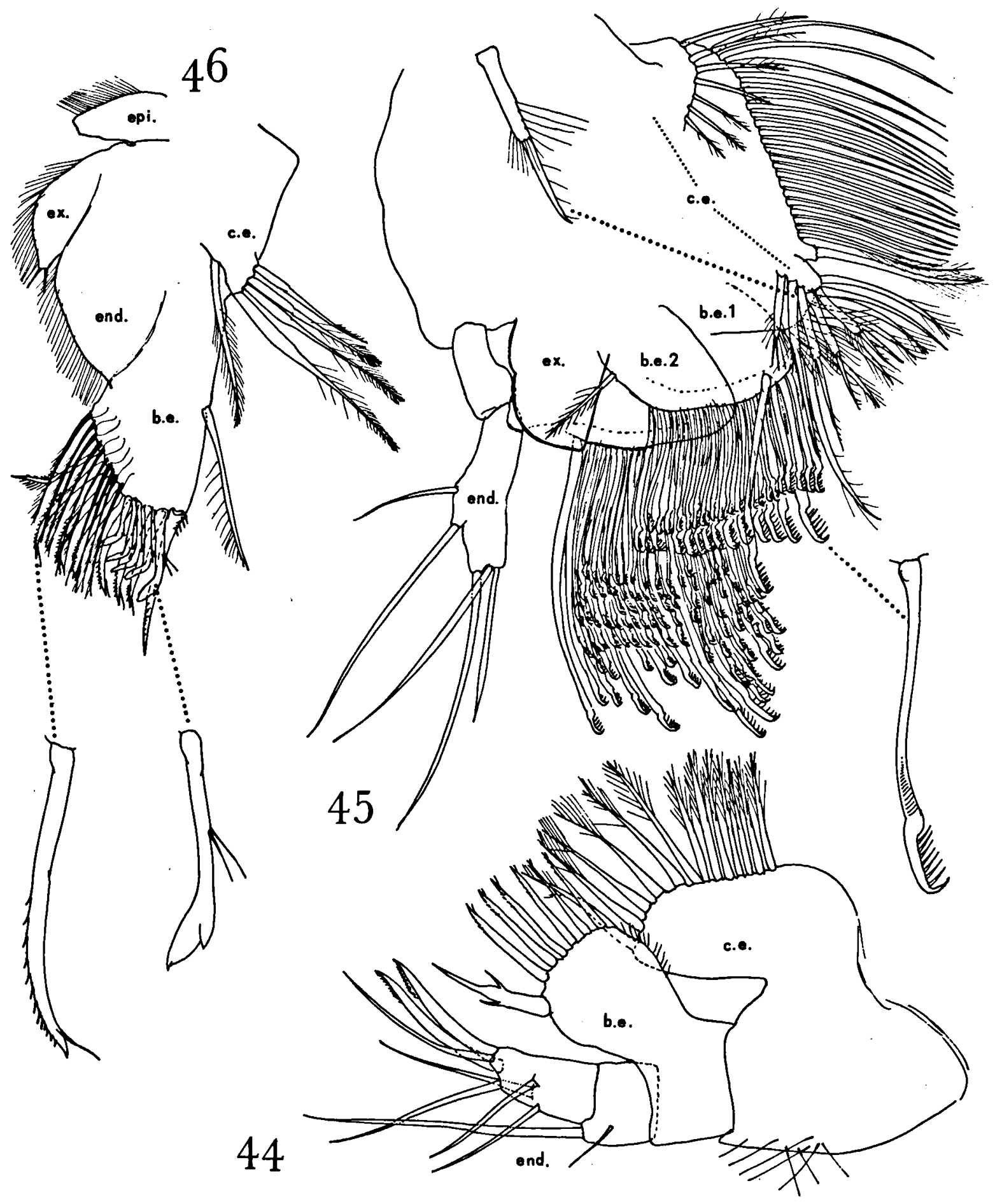

Figs. 44-46. Halosbaena acanthura n. gen., n. sp., paratypes. 44, first maxilla, $\delta$ (scale G); 45, second maxilla, 9 (scale G); 46, maxilliped, ơ (scale K).

b.e. $=$ basipodal endite; c.e. $=$ coxopodal endite; end. = endopodite; epi. = epipodite; ex. = exopodite. 
exopodites, gradually decreasing in size from anterior to posterior. The number of elements on exopodite article 1 is 1 plumose seta (P2-P7), on article 2 it is 8 plumose setae (in P2-P5), or 6 plumose setae (P6), or 4 plumose setae (P7). The basis bears a lateral setule (P2-P7). The ischiomerus bears 1 distal seta (P2) or 1 subbasal setule +1 distal seta (P3-P7). The carpus bears 2 medial setae (P2-P6) or only 1 (P7) and 1 short lateral seta (P2-P7). The propodus is short in $\mathrm{P} 2$, longer in the posterior pereiopods; it bears 2 medial setae and 1 distolateral plumose seta in all legs; in P3-P7, there is also a smaller subdistal setule on the lateral margin. The dactylus bears 2 elements on its inner (= medial) margin. The ungulus is distally finely toothed.

In males, the 7 th pereiopod bears an elongated penis (fig. 54).

The first urosomite bears lateroventrally a tapering process, distally provided with a thin, but plumose, seta; near the unarticulated base of this process 2 strong spines arise (fig. 29). Along the posterior margin of urosomite 1 , going in dorsal direction from the process, one observes another strong spine, and a row of about 6 very thin setules. This complex structure, or probably only the tapering process with its 3 elements, is presumed to be the rudiment of the first pleopod (cf. figs. 28, 29, 30, 31).

The 2nd urosomite bears a pleopod which resembles that of Thermosbaena and Monodella. It is well-articulated at the base, and bears 3 lateral and 1 terminal setae (fig. 32).

The uropod (fig. 34) has a 2-segmented exopodite and a 1-segmented endopodite, the latter reaching to about $4 / 3$ of the former. Exopodite article 1 bears 4 smaller and 1 longer lateral spines and some lateral cilia; medially it usually bears 5 feathered setae. Exopodite article 2 bears 10 to 15 plumose setae regularly dispersed on the lateral, distal, and medial margins. The endopodite bears plumose setae and spines on the medial margin; the distalmost of the spines is much enlarged and denticulate; the distal and

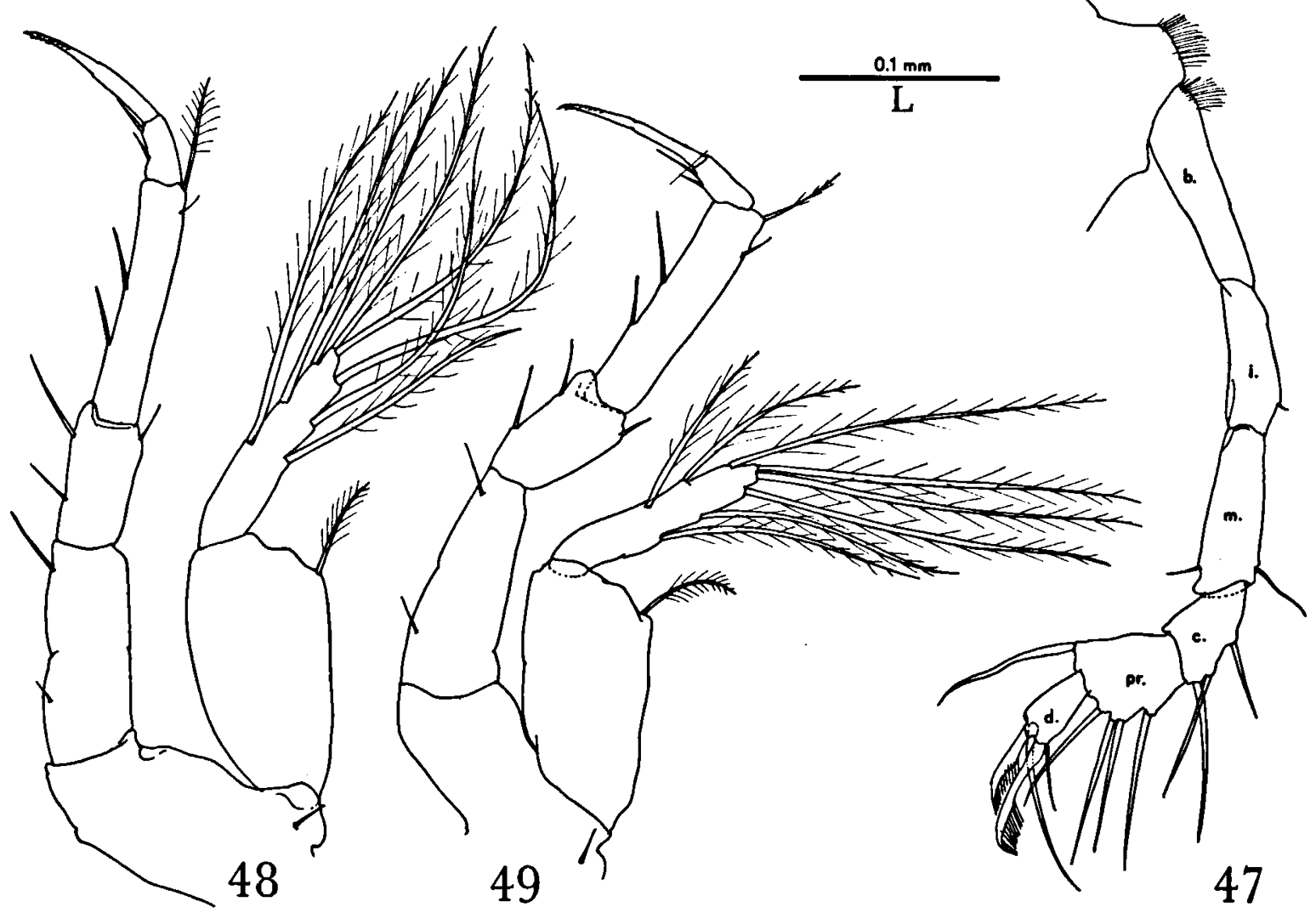

Figs. 47-49. Halosbaena acanthura n. gen., n. sp., $\$$, paratype. 47, first pereiopod; 48, fourth pereiopod; 49 , fifth pereiopod (all to scale $L$ ).

b. = basis; i. = ischium; m. = merus; c. = carpus; pr. = propodus; d. = dactylus. 


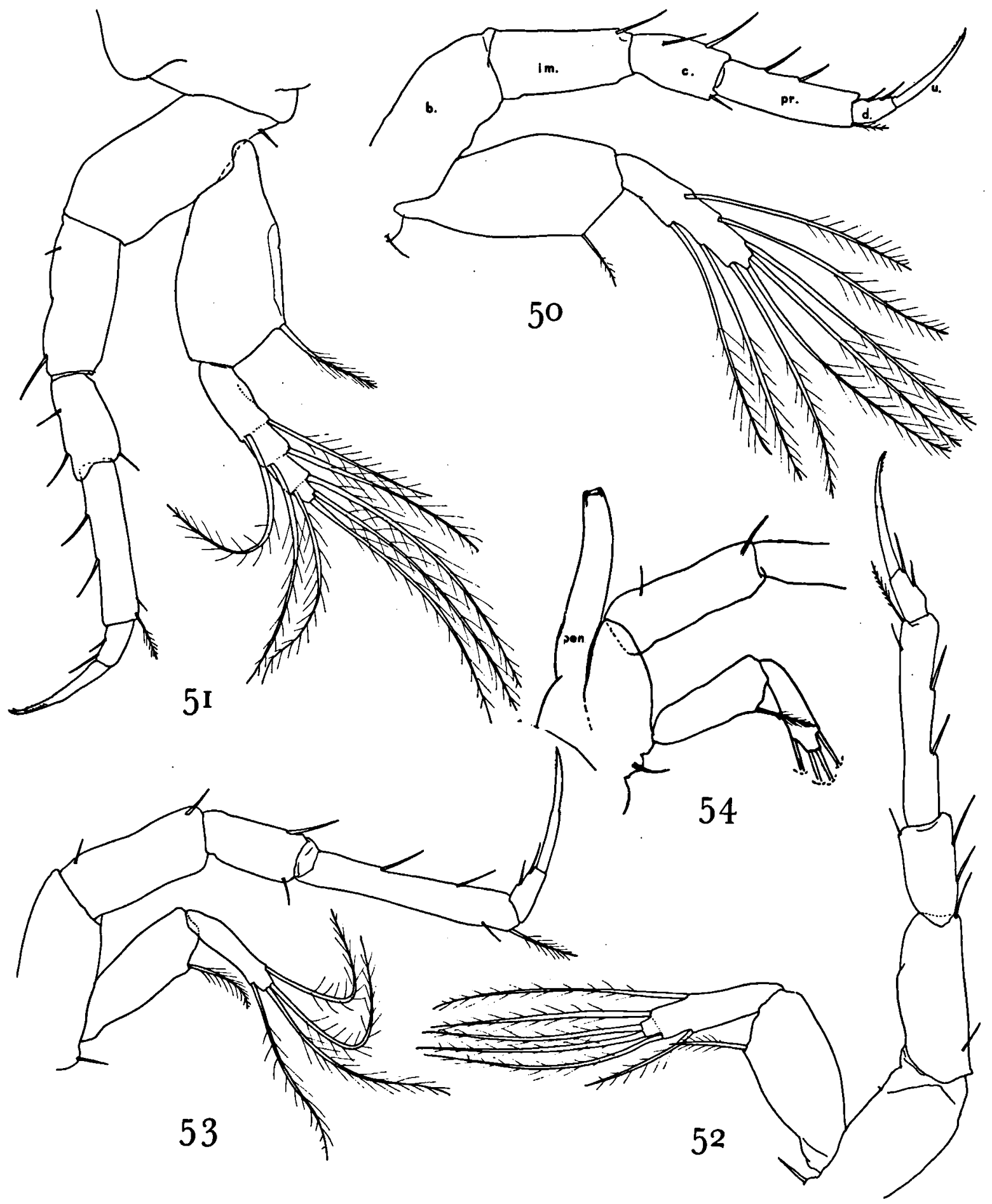

Figs. 50-54. Halosbaena acanthura n. gen., n. sp., paratypes. 50, second pereiopod, $\%$; 51 , third pereiopod, $\% ; 52$, sixth pereiopod, $q ; 53$, seventh pereiopod, $\& ; 54$, basal part of seventh pereiopod, $\delta$, with penis (all to scale $\mathrm{L}$ ).

b. = basis; im. = ischiomerus; c. = carpus; pr. = propodus; $d .=$ dactylus; $u_{.}=$ungulus; pen. = penis. 
mediodistal margins bear plumose setae only.

The telson is tapering, distally rounded (fig. 35). The marginal armature consists of 5 smooth spines and 4 foliate spines on either side; moreover there is 1 pair of small dorsal spines. Presumably, the anus opens on the ventral surface of the basal half of the telson, at a place indicated by two flaps (fig. 28).

\section{III.3. Affinities. -}

As discussed below (8 IV), Halosbaena resembles in certain respects the new genus Limnosbaena. The great number of specialized elements on the 2nd maxilla, common to both genera, might partially be a convergent development, based on identical food requirements. As a matter of fact, the maxillar combed spines look like a kind of sieve for obtaining the finest detritus or perhaps flocculent, partly decomposed, organic matter.

Halosbaena has so many peculiarities in its external morphology, that it is no doubt the most aberrant thermosbaenacean known at the moment. As explained elsewhere (8 VI), it is not unlikely that Halosbaena is, in contradistinction to the other thermosbaenaceans, a fairly recent (Pleistocene) invader of the coastal interstitium. This makes it tempting to think of Halosbaena as a form having preserved much of the morphology of the unknown marine ancestors of the group. On the other hand, the morphology of the mouth parts, the maxilliped and the first pereiopod in Halosbaena is certainly not primitive, on the contrary it is highly adapted.
It must be remarked that the first three localities from which Halosbaena is recorded (8 III.2.) are of a hyperhaline nature; the fourth locality (Jan Thiel Bay) is approximately marine, the fifth is euhaline. None of the known localities can be classified as brackish (mixohaline).

\section{Limnosbaena n. gen.}

Monodella finki Meštrov \& Lattinger-Penko, 1969 deviates in so many respects from the other five recognized species of Monodella, that there can hardly be any doubt that it represents a different, as yet unnamed, genus.

I call this new genus Limnosbaena, a modified contraction of the Greek words $\lambda i \mu v \eta$ (referring to the limnic habitat) and Baiverv (to walk). The salient differences from Monodella are enumerated in table I.

Curiously enough, this Bosnian freshwater taxon shows several morphological similarities to Halosbaena from haline habitats in Curaçao. These similarities bear on the presence of a bilobate rostrum, the reduction of the right mandibular lacinia mobilis, the overall morphology of the second maxilla as well as the presence of supernumerary elements on its basipodal endites 1 and 2, the 2-segmented nature of the exopodite in the 6th pereiopod, and the reduction of the first pleopod. On the other hand, the genus Halosbaena is perfectly characterized, against both Monodella and Limnosbaena, by a number of very original features, such as the

Table I. Salient differences between Monodella Ruffo, 1949, and Limnosbaena n. gen.

\begin{tabular}{|c|c|c|}
\hline & Monodella & Limnosbaena \\
\hline 1) Al, main flagellum & 7- to 14-segmented & 4-segmented \\
\hline 2) Al, accessory flagellum & 5-segmented & 3-segmented \\
\hline 3) A2, peduncle & articles 4 and 5 elongated & article 3 elongated \\
\hline 4) Md., lacinia mobilis & present on left and right side & $\begin{array}{l}\text { present left, almost entirely rudimentary } \\
\text { on the right side }\end{array}$ \\
\hline 5) Md., pars molaris & trapezoidal, distally rounded or truncated & almost spiniform, elongated and pointed \\
\hline 6) Mx2, basipodal endite 2 & narrow, with about 6 special spines & $\begin{array}{l}\text { widened, with about } 50 \text { elements, including } \\
\text { special spines }\end{array}$ \\
\hline 7) Mxp., exopodite & 2-segmented, longer than basipodal endite & l-segmented, shorter than basipodal endite \\
\hline 8) Pl-P5, exopodal article 2 & elongated, as long as article 1 & small, knob like, $<<$ article 1 \\
\hline 9) P2-P7, endopodal ischium & fused with merus & free \\
\hline 10) P6, exopodite & 1-segmented & 2-segmented \\
\hline 11) pleopods 1 and 2 & well-developed, elongated & wider than long \\
\hline 12) uropod, exopodite & $\begin{array}{l}\text { article } 2 \text { as long as article } 1 \text {; } \\
\text { exopodite twice as long as endopodite }\end{array}$ & $\begin{array}{l}\text { article } 2 \text { reduced; } \\
\text { exopodite as long as endopodite }\end{array}$ \\
\hline
\end{tabular}

$A 1=$ first antenna; $A 2$ = second antenna; $M d .=$ mandible; $M \times 2=$ second $\operatorname{maxilla} ;$ Mxp. $=$ maxilliped; $P 1-P 7=$ pereiopods 1 to 7 . 
plate-like widening of the (unarmed) maxillar exopodite, the strong reduction of the endopodite in the maxilliped, and the reduction to a single-segmented, poorly armed, stub of the maxillipedal exopodite, the absence of an exopodite and the nature of the endopodal segmentation in the first pereiopod, the 2-segmented nature of the exopodite in the seventh pereiopod, and the reduction of the first, but the presence of the second pleopod. In the shape of the pars molaris of the mandible, in the relative lengths of the articles of the second antenna, and in the relative lengths of the articles of the uropod, the genus Halosbaena occupies a position somewhat intermediate between Monodella and Limnosbaena.

Diagnosis of the new genus Limnosbaena. -

Thermosbaenacea with 7 pairs of pereiopods and a free telson. Rostrum present, bilobed. First antenna with reduced number of articles in main flagellum (4) or accessory flagellum (3). Limit between peduncle and flagellum in second antenna not clearly marked. Lacinia mobilis distinct in left mandible, rudimentary in the right one; pars molaris almost spiniform, elongated, pointed. Second maxilla with small exopodite bearing a seta, basipodal endites 1 and 2 widened, each provided with numerous specialized elements. Maxilliped with 5-segmented endopodite in male, and short 1-segmented exopodite. Exopodites of pereiopods 1 to 6 bimerous, distal segment small. Exopodite of pereiopod 7 1segmented. Pleopods 1 and 2 rudimentary, wider than long. Telson elongately trapezoidal, without marginal spines. Rami of uropod subequal.

\section{KEY TO THE GENERA OF THERMOSBAENACEA $(\%, \sigma)$}

The two thermosbaenacean genera already known, and the two new genera described in this paper, can be distinguished as follows:

1a) Five pairs of pereiopods present. Telson fused with 3rd urosomite. Maxilliped without endopodite in both sexes ... . . . . . . Thermosbaena Monod, 1924

b) Seven pairs of pereiopods present. Telson separated from 3rd urosomite. Maxilliped with endopodite, at least in $\delta$ ................ 2

2a) First pereiopod uniramous. Maxillipedal endopodite reduced to a poorly armed rudiment, not sexually dimorphic. Exopodite of seventh pereiopod 2-segmented . . b) First pereiopod biramous. Maxillipedal endopodite sexually dimorphic, strongly developed in male. Exopodite of seventh pereiopod 1-segmented . . . . . . 3

3a) Exopodite of sixth pereiopod 2-segmented. Maxillipedal exopodite 1-segmented. Second maxilla with numerous extra elements. . . . . . . . Limnosbaena n. gen.

b) Exopodite of sixth pereiopod 1-segmented. Maxillipedal exopodite 2-segmented. Second maxilla without supernumerary elements . . . . Monodella Ruffo, 1949

\section{DISTRIBUTION AND ORIGIN OF THE THER- MOSBAENACEA}

When Monod, 1924, described the first member of the Thermosbaenacea from saline, hot springs in Tunisia, he recognized at once that this animal showed relationship with several other crustaceans, like mysids, tanaids, and isopods, but was sufficiently distant from all of these to justify the erection of a special order. Since then, the Thermosbaenacea have alternately been considered either an order of the superorder Peracarida (Monod, 1940; Barker, 1960, 1962; Gordon, 1964), or a superorder of its own, the Pancarida (Siewing, 1958), whereas still others have placed them between the Peracarida and Syncarida (Stella, 1953; Taramelli, 1954). The first of these three alternative views is the most frequently adhered one, and is supported by firm evidence (Barker, 1962; Fryer, 1965).

A small number of other thermosbaenaceans has been discovered after World War II, so that the order up to now comprised 2 genera (Thermosbaena Monod, 1924, and Monodella Ruffo, 1949) and 7 named species (Th. mirabilis Monod, 1924; Monodella stygicola Ruffo, 1949; $M$. argentarii Stella, 1951; $M$. halophila Karaman, 1953; $M$. relicta Pór, 1962; M. texana Maguire, 1965, and $M$. finki Meštrov \& Lattinger-Penko, 1969). Of these, $M$. halophila is most probably a junior synonym of $M$. argentarii (vide Rouch, 1965), and $M$. finki is raised to a separate generic rank (see 8 IV). Furthermore, unspecified thermosbaenaceans from vaguely indicated localities are recorded by Bou, 1975b ("Andalusia" and "Bouches-du Rhône") and by Botosaneanu \& Delamare Deboutteville, 1967 ("France"). The distribution of these thermosbaenaceans is plotted on the maps shown in fig. 55. All except one species are found around the Mediterranean, the one exception being a species recorded from Texas (U.S.A.). The present paper records 2 new 


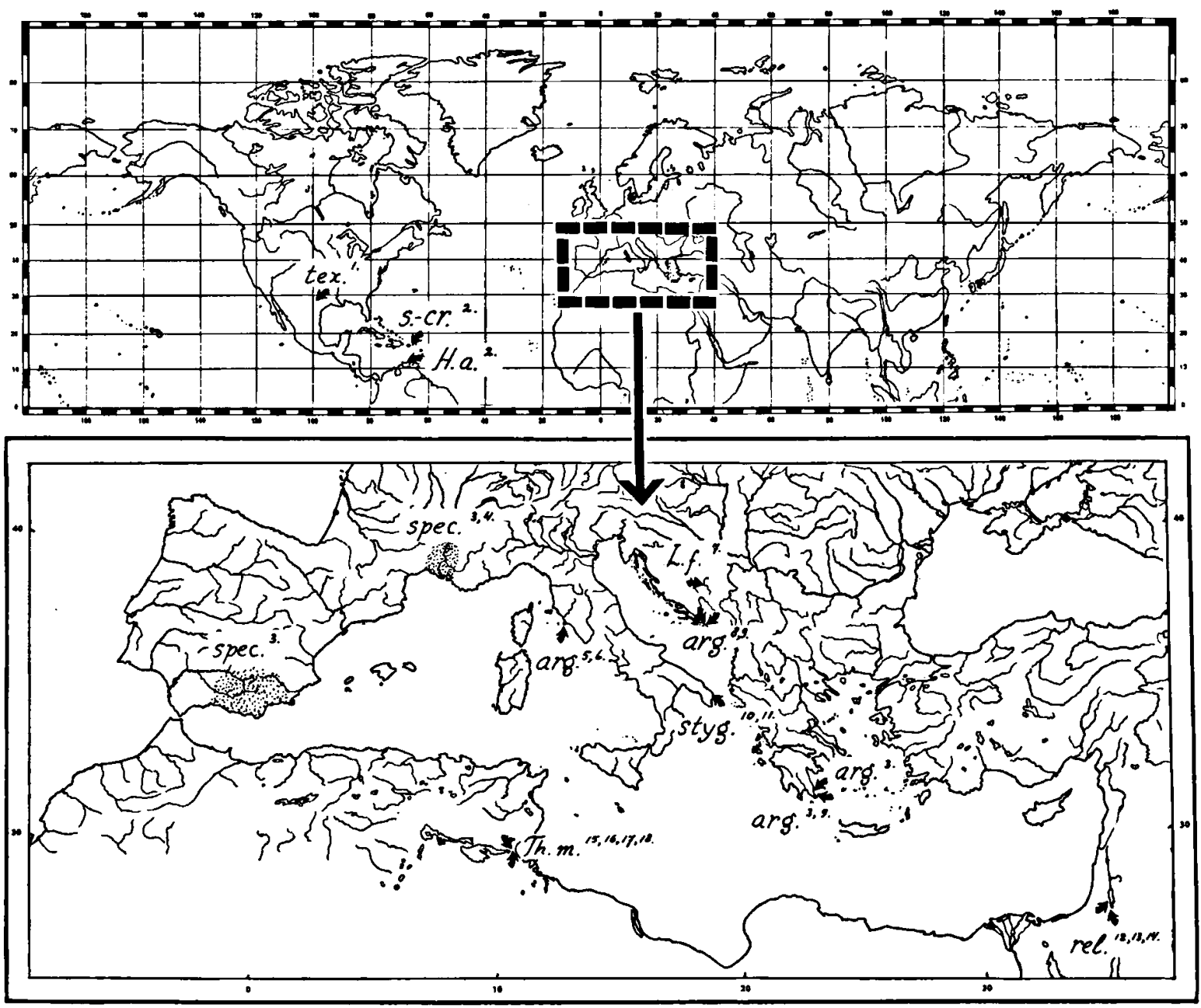

Fig. 55. The distribution of the order Thermosbaenacea: one named taxon is known from North America, two from the Antilles, whereas the remaining have been found around the Mediterranean basin.

Th.m. = Thermosbaena mirabilis Monod, 1924; L.f. = Limnosbaena finki (Meštrov \& Lattinger-Penko, 1969); H.a. = Halosbaena acanthura n. gen., n. sp.; arg. = Monodella argentarii Stella, 1951; rel. = $M$. relicta Pór, 1962; s.-cr. = M. sanctaecrucis n. sp.; styg. $=M$. stygicola Ruffo, 1949; tex. $=M$. texana Maguire, 1965; spec. $=$ unidentified thermosbaenaceans.

Arrows represent firmly localized records; dotted areas represent vaguely indicated records. I have followed Rouch, 1965, in considering $M$. halophila Karaman, 1953, synonymous with $M$. argentarii. The figures at the localities refer to the papers cited below; in certain cases, only the most complete locality record is shown in the map. Not shown in the map are the recent records of an unidentified Monodella from several localities in Majorca (Orghidan et al,. 1975).

1 = Maguire, 1964, 1965

$2=$ present paper

$3=$ Bou, 1975b

4 = Botosaneanu \& Delamare Deboutteville, 1967

5 = Stella, 1951a

6 = Stella \& Salvadori, 1953

7 = Meštrov \& Lattinger-Penko, 1969

8 = Karaman, 1953

$9=$ Rouch, 1965
$10=$ Ruffo, 1949a

11 = Ruffo, 1949b

12 = Pór, 1962

13 = Pór, 1963

14 = Tsurnamal \& Pór, 1971

15 = Barker, 1959

16 = Bruun, 1939

17 = Monod, 1924

18 = Monod, 1940 
taxa from Caribbean islands, bringing the total number of valid species of thermosbaenaceans to 8. Most species have been found in waters with a raised ion-content, but at least 2 are purely limnic.

Karaman, 1953, 1954, and others, consider the ancestors of the Thermosbaenacea to have been of marine origin. Barker $(1959,1960)$ suggested that the members of the group were (and still are) interstitial animals, whose ancestral habitat was the ancient Tethys Sea. He discussed at some length two hypotheses to account for the actual distribution of the thermosbaenaceans.

The first of these hypotheses followed the ideas of Bruun (1939) and Ruffo (1949b), in that the animals were "stranded" as result of the retreat of the ancient Tethys Sea, showing a relic distribution of marine origin in the pan-mediterranean region. In an able discussion of the topic, Fryer (1965) made it highly probable that this "stranding" must have taken place in MiocenePliocene times, as is evidenced by the distribution of land and water in the various geological periods and by the actual distribution of a number of other relics (the isopods Typhlocirolana and Monolistera, the decapod Typhlocaris, and the mysid Troglomysis). Fryer concluded that quite a few of the pan-mediterranean marine relics are found in areas covered by seawater in the Mid-Miocene, but above sea-level in the Pliocene, so that the "stranding" must have taken place in between.

The second of Barker's hypotheses assumes a much more recent origin of the thermosbaenaceans, for instance during lacustrine periods in the late Pliocene or Quarternary. The main support for this second hypothesis was the fact that when Barker wrote his account all thermosbaenacean records were from near-coast habitats (brackish waters in caves close to the sea, in mesopsammal beach assemblages, or near desiccated salty lagoons), suggestive of a more recent freshwater invasion.

Since the early 1960's, the discovery of various new thermosbaenaceans in other habitats forms strong evidence for the older theory, that of a Tethys origin of the group. These recent discoveries comprise a species from the Dead Sea depression, it is true in a salty habitat, but distinctly in a relic situation (Pór, 1962, 1963; Tsurnamal \& Pór, 1971), and two species from purely limnic habitats. One of these was recorded by Maguire $(1964,1965)$ from cave waters in Texas, U.S.A. (altitude $180 \mathrm{~m}, 200 \mathrm{~km}$ from the nearest sea-coast), another by Meštrov \& Lattinger-Penko (1969) from groundwater in Bosnia (altitude $354 \mathrm{~m}, 120 \mathrm{~km}$ from the coast). The occurrence in entirely fresh water is, of course, a point in favour of a rather ancient penetration of the continental subterranean waters (e.g., Miocene-Pliocene, cf. Fryer, 1965), instead of a rather recent one (late Pliocene-Quarternary, cf. Barker, 1959, 1960).

It is significant, moreover, that the two species of Monodella from the Western Hemisphere are morphologically very similar to Eastern Hemisphere species of the same genus. This seems to point to a uniformly distributed ancestral form of Monodella in great parts of the Tethys basin, from which the various inland invasions originated. The new genus Halosbaena, collected in salty habitats in the West Indies, is distinctly related to the limnic genus Limnosbaena from Jugoslavia.

These facts make unlikely one of Maguire's hypotheses (1964: 932), according to which "invasion of fresh water by these crustaceans occurred independently and recently in at least two widely separated parts of the world", and that "marine members of the order then became extinct (or have not yet been found)". In my opinion, the antiquity of the group cannot longer be doubted.

Geological evidence for Monodella sanctaecrucis points in the same direction as Fryer's conclusion for the pan-mediterranean thermosbaenaceans, viz. a Miocene-Pliocene origin. The area of St. Croix was dry land in the middle and late Eocene (Woodring, 1954, fig. 2; Weyl, 1966, fig. 119), submerged in the late Oligocene and early Miocene (Woodring, 1964, fig. 3), whereas after the early Miocene, the area was uplifted and has since then probably been above sea level (Whetten, 1966: 233).

For Halosbaena acanthura from Curaçao the situation might quite well be different, according to indirect geological and ecological evidence. According to De Buisonjé (1974: 249) Curaçao was formed in late Miocene or Pliocene times, as reefs around shoals or islands of a size much smaller than the present island. During the regional tectonic uplift ever larger areas emerged. Weyl (1966: 280) presumed that during the Pleistocene marine transgression the entire island, but for the mountanous northwestern part, 


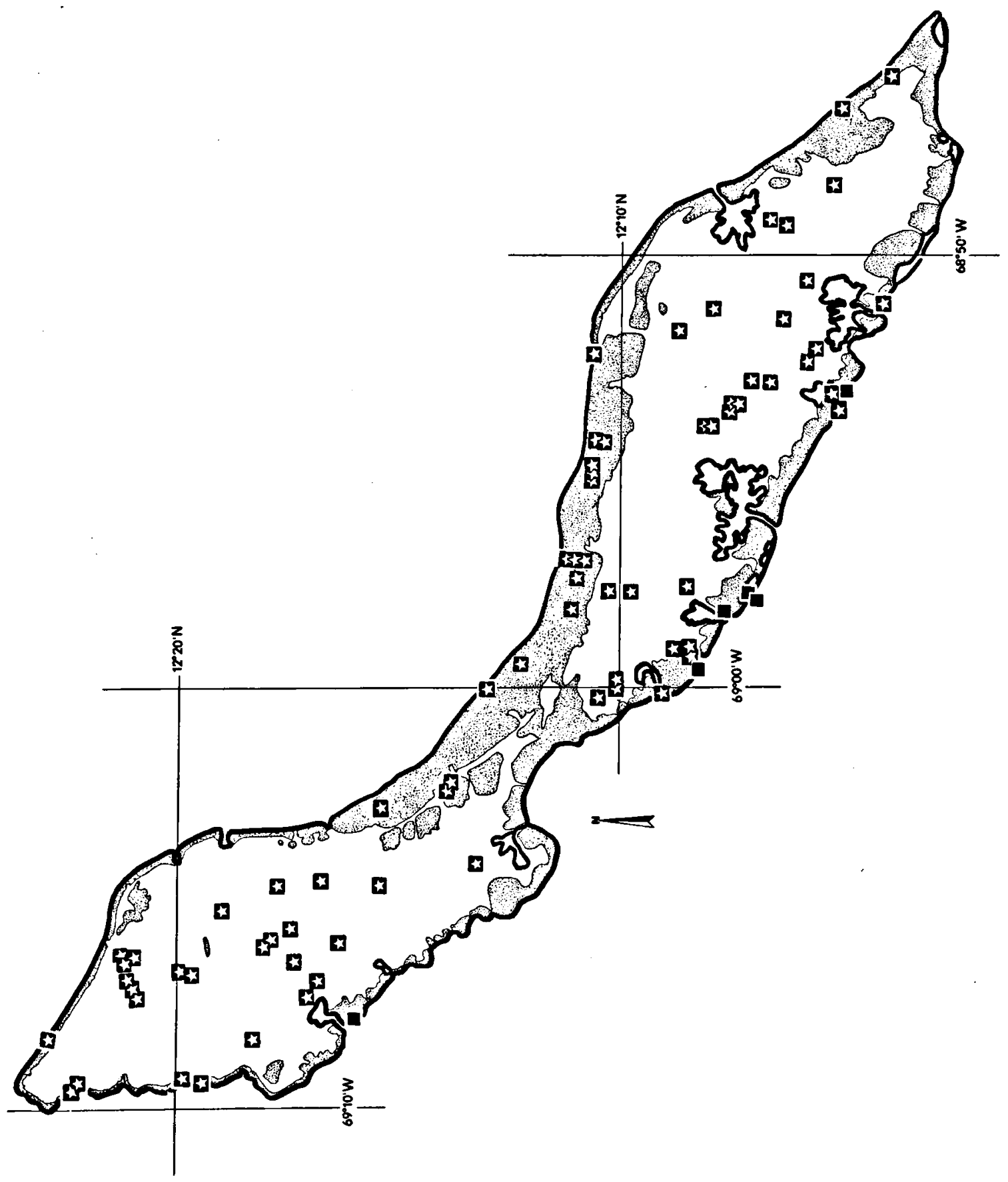

Fig. 56. Map of Curaçao with the distribution of the stations sampled for aquatic subterranean (including interstitial) fauna (open symbols). Localities of Halosbaena acanthura indicated by closed symbols. Dotted are areas with Quarternary or Pleistocene marine deposits, of which it is certain that they were submerged during the transgression period Probably, larger areas were below sea-level. 
was submerged again. De Buisonjé (1974: 249) believes that during the old Pleistocene two nuclei remained above sea-level, viz. the northwestern and southeastern part of the island. In between these two pieces of dry land, a landbridge arose (at the place where the actual island shows its "narrow waist") during slow regressions in the Quarternary or Pleistocene. The latter idea (two islands merging into one) is supported by the rather considerable number of endemics, e.g. of land snails, in Curaçao.

As far as Halosbaena is concerned, it might be significant that all its localities (in 6 out of 80 samples from Curaçao, cf. fig. 56) are situated in Quarternary of Neogene limestone deposits (Beets, 1972, pls. I, II) or in Recent or Subrecent coral shingle (De Buisonjé, 1974, maps 1, 2), in areas that were submerged in Pleistocene times.

Together with the obvious halophily of Halosbaena, this seems to indicate that this taxon is a fairly recent invader of macroporous interstitial waters. Morphologically, Halosbaena is not primitive, however, so it hardly classifies as (one of) the presumed marine ancestor(s) of the thermos- baenaceans (vide 8 III.3).

The discoveries, in the last few years, of limnic interstitial thermosbaenaceans, as well as of American and Caribbean forms, show how right Delamare's prediction has been (1960: 248): "Je pense personellement qu'on les retrouvera en bien des coins du monde dans les régions souterraines littorales où des systèmes karstiques noyés voisinent avec des milieux interstitils macroporaux". I must add, that the discovery of a possible Pleistocene immigrant of the interstitium (viz., Halosbaena) makes it more probable than ever that marine thermosbaenaceans are still to be discovered.

Distribution patterns similar to that of the Thermosbaenacea (pan-mediterranean and pancaribbean, in subterranean, chiefly saline, waters) are shown by several other crustaceans like Stygiomysis (Mysidacea) and stenaselline isopods.

In several instances (e.g. the amphipods Hadzia and Eriopisa), the distribution is even larger, including also Indo-Pacific parts of the ancient Tethys Sea.

\section{BIBLIOGRAPHY}

of the Thermosbaenacea and other references ${ }^{1}$ )

BARKER, D., 1956. The morphology, reproduction and behaviour of Thermosbaena mirabilis Monod. Proc. XIV int. Congr. Zool. 1953: 503-504 (Danish Science Press, Copenhagen).

- , 1959. The distribution and systematic position of the Thermosbaenacea. Hydrobiologia, 13 : 209-235.

,- 1960 . On Thermosbaena mirabilis Monod and the distribution and systematics of the Thermosbaenacea. Proc. cent. bicent. Congr. Biol. (Singapore, 1958) : 253-258 (Univ. Malaya Press, Singapore).

-, 1962. A study of Thermosbaena mirabilis (Malacostraca, Peracarida) and its reproduction. Quart. J. microsc. Sci., $103(2): 261-286$.

BeETs, D. J., 1972. Lithology and stratigraphy of the Cretaceous and Danian succession of Curaçao. Uitg. natuurw. Studiekring Suriname Ned. Ant., 70: 1-153, phots. I-21, pls. I-VI.

Botosaneanu, L. \& Cl. Delamare Deboutteville, 1967. Fossiles vivantes des eaux souterraines. Sciences (Paris), $52: 17-22$.

Bou, C., 1975a. Les méthodes de récolte dans les eaux souterraines interstitielles. Annls. Spéléol., 29 (4) : 611-619.

1) Several older references are not enumerated here, but can be found in the papers of Barker, 1959, and Monod, 1940.
- 1975b. Recherches sur la faune des eaux souterraines de Grèce. Biologia gallo-hell., 6(1) : 101-115.

BruUn, A. F., 1939. Observations on Thermosbaena mirabilis Monod from the hot springs of El-Hamma, Tunisia. Vidensk. Meddr. dansk naturh. Foren., 103 : 492-501.

Buisonjé, P. H. DE, 1974. Neogene and Quarternary geology of Aruba, Curaçao and Bonaire. Uitg. natuurw. Studiekring Suriname Ned. Ant., $78: 1-293$, maps $1-4$.

Delamare Deboutteville, Cl., 1960. Biologie des eaux souterraines littorales. Actualités sci. indust., $1280: 1-740$ (Thermosbaenacea: 241-248, 544, 627-630) (Hermann, Paris).

FrYer, G., 1965. Studies on the functional morphology and feeding mechanism of Monodella argentarii Stella (Crustacea: Thermosbaenacea). Trans. R. Soc. Edinburgh, 66 (4) : 49-90.

GoRdon, I., 1958. A thermophilous shrimp from Tunisia. Nature (London), 182 (4644) : 1186.

-, 1964. On the mandible of the Stygocaridae (Anaspidacea) and some other Eumalacostraca, with special reference to the lacinia mobilis. Crustaceana, 7 (2): 150-157.

Hessler, R. R., 1969. Order Thermosbaenacea. In: R. C. MOORE, ed., Treatise on invertebrate palaeontology, part R. Arthropoda, 4 (vol. 1): R366-R367 (Geol. Soc. Am., Boulder, Colorado). 
Karaman., S. L., 1953. Ueber einen Vertreter der Ordnung Thermosbaenacea (Crustacea Peracarida) aus Jugoslavien, Monodella halophila n. sp. Acta adriat., 5(3) : 1-22.

- , 1954. Uber unsere unterirdische Fauna [In Serbian, with German summary]. Acta Mus. maced. Sci. nat., 1 (9) : 195-216.

Maguire, JR., B., 1964. Crustacea: A primitive mediterranean group also occurs in North America. Science (Washington), 146 (3646) : 931-932.

-, 1965. Monodella texana $\mathrm{n}$. sp., an extension of the range of the crustacean order Thermosbaenacea to the Western Hemisphere. Crustaceana, 9 (2) : 149-154, pl. III.

Meštrov, M. \& R. Lattinger-Penko, 1969. Sur la présence de Thermosbaenacés (Crustacea, Peracarida) dans les eaux interstitielles continentales de la Yougoslavie (Monodella finki n. sp.). Annls. Spéléol., 24 (1) : 111-123.

Monod, TH., 1924. Sur un type nouveau de Malacostracé: Thermosbaena mirabilis nov. gen. nov. sp. Bull. Soc. zool. Fr., 49 (2) : 58-68.

-, 1927a. Nouvelles observations sur la morphologie de Thermosbaena mirabilis. Bull. Soc. zool. Fr., 52 (3): 196-200.

,$- 1927 b$. Thermosbaena mirabilis Monod - Remarques sur sa morphologie et sa position systématique. Faune Colon. fr., $1(2): 29-51$.

-, 1940. Thermosbaenacea. Bronn's Kl. Ordn. Tierreichs, Bd. 5, Abt. 1, Buch 4, Teil IV: 1-24.

NoodT, W., 1974. Anpassung an interstitielle Bedingungen: ein Faktor in der Evolution höherer Taxa der Crustacea? Faun.-ökol. Mitt., 4: 445-452.

Orghidan, T., M. Dumitresco \& M. Georgesco, 1975. Mission biospéologique "Constantin Dragan" à Majorque. Première note: Arachnides. Trav. Inst. Spéol. "E. Racovitza", 14:9-33.

Pór, F. D., 1962. Un nouveau Thermosbaenacé, Monodella relicta n. sp. dans la dépression de la Mer Morte. Crustaceana, 3 (4) : 304-310, pl. VII.

- , 1963. The relict aquatic fauna of the Jordan Rift Valley. Israel J. Zool., $12(1-4): 47-58$.

Rouch, R., 1965. Contribution à la connaissance du genre Monodella (Thermosbaenacés). Annls. Spéléol., 19 (4) : 717-727.

Ruffo, S., 1949a. Monodella stygicola n. g. n. sp. nuovo Crostaceo Thermosbenaceo delle acque sotterranee della
Penisola Salentina. Archo. zool. ital., 34 : $31-48$.

-, 1949b. Sur Monodella stygicola Ruffo des eaux souterraines de l'Italie méridionale, deuxième espèce connue de l'ordre des Thermosbaenacés (Malacostraca Peracarida). Hydrobiologia, 2 : $56-63$.

Siewing, R., 1958. Anatomie und Histologie von Thermosbaena mirabilis. Abh. math.-naturw. Kl. Akad. Wiss. Mainz, 1957 (7) : 195-270.

StellA, E., 1951a. Monodella argentarii n. sp. di Thermosbaenacea (Crustacea Peracarida) limnotroglobio di Monte Argentario. Archo. zool. Ital., $36: 1-15$.

,$- 1951 b$. Notizie biologiche su Monodella argentarii Stella, Thermosbenaceo delle acque di una Grotta di Monte Argentario. Boll. Zool., 18 : 227-233.

-, 1953. Sur Monodella argentarii Stella, espèce de Crustacé Thermosbaenacé des eaux d'une grotte de l'Italie centrale (Monte Argentario, Toscana). Hydrobiologia, 5: 226-234

-, 1955. Behaviour and development of Monodella argentarii Stella, a thermosbenacean from an Italien cave. Verh. int. Ver. Limnol., $12: 464-466$.

- , 1959. Ulteriori osservazioni sulla riproduzione e lo sviluppo di Monodella argentarii (Pancarida Thermosbaenacea). Riv. Biol., 51 : $121-144$.

Stella, E. \& F. B. Salvadori, 1953. La fauna acquatica della grotta "di punta degli Stretti" (Monte Argentario). Archo. zool. ital., 38 (2) : $441-483$, pls. I-II.

TARAMELLI, E., 1954. La posizione sistematica dei Thermosbenacei quale risulta dallo studio anatomico di Monodella argentarii Stella. Monitore zool. ital., 62 (1) : 9-24, pls. I-III.

Tsurnamal, M. \& F. D. Pór, 1971. The subterranean fauna associated with the blind palaemonid prawn Typhlocaris galilea Calman. Int. J. Speleol., 3 (3/4) : 219-223, pl. LXIX.

VANDEL, A., 1964. Biospéologie - La biologie des animaux cavernicoles: i-xviii, 1-619 (Thermosbaenacés: 142-145) (Ed. Gauthier-Villars, Paris).

Weyt, R., 1966. Geologie der Antillen. Beitr. reg. Geol. Erde, 4 : i-viii, $1-410$ (Gebr. Bornträger, Berlin).

Whetten, J. T., 1966. Geology of St. Croix, U. S. Virgin Islands. Mem. geol. Soc. Am., 98 : 177-239.

Woodring, W. P., 1954. Caribbean land and sea through the ages. Bull. geol. Soc. Am., 65 : 719-732, pl. I. 